\title{
2011s-63
}

\section{Why didn't the Global Financial Crisis hit Latin America?}

\author{
Tjeerd M. Boonman, Jan P.A.M. Jacobs, Gerard H. Kuper
}

\begin{tabular}{c}
\hline Série Scientifique \\
Scientific Series
\end{tabular}

\section{Montréal}

Octobre 2011

(C) 2011 Tjeerd M. Boonman, Jan P.A.M. Jacobs, Gerard H. Kuper. Tous droits réservés. All rights reserved. Reproduction partielle permise avec citation du document source, incluant la notice $\odot$.

Short sections may be quoted without explicit permission, if full credit, including (C) notice, is given to the source.
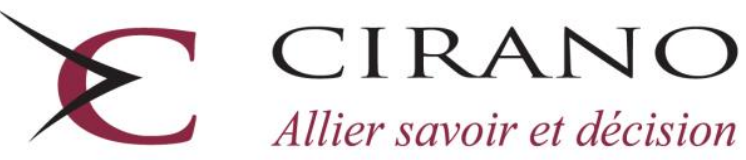

Allier savoir et décision

Centre interuniversitaire de recherche en analyse des organisations 


\section{CIRANO}

Le CIRANO est un organisme sans but lucratif constitué en vertu de la Loi des compagnies du Québec. Le financement de son infrastructure et de ses activités de recherche provient des cotisations de ses organisations-membres, d'une subvention d'infrastructure du Ministère du Développement économique et régional et de la Recherche, de même que des subventions et mandats obtenus par ses équipes de recherche.

CIRANO is a private non-profit organization incorporated under the Québec Companies Act. Its infrastructure and research activities are funded through fees paid by member organizations, an infrastructure grant from the Ministère du Développement économique et régional et de la Recherche, and grants and research mandates obtained by its research teams.

\section{Les partenaires du CIRANO}

\section{Partenaire majeur}

Ministère du Développement économique, de l'Innovation et de l'Exportation

\section{Partenaires corporatifs}

Autorité des marchés financiers

Banque de développement du Canada

Banque du Canada

Banque Laurentienne du Canada

Banque Nationale du Canada

Banque Royale du Canada

Banque Scotia

Bell Canada

BMO Groupe financier

Caisse de dépôt et placement du Québec

\section{CSST}

Fédération des caisses Desjardins du Québec

Financière Sun Life, Québec

Gaz Métro

Hydro-Québec

Industrie Canada

Investissements PSP

Ministère des Finances du Québec

Power Corporation du Canada

Rio Tinto Alcan

State Street Global Advisors

Transat A.T.

Ville de Montréal

\section{Partenaires universitaires}

École Polytechnique de Montréal

HEC Montréal

McGill University

Université Concordia

Université de Montréal

Université de Sherbrooke

Université du Québec

Université du Québec à Montréal

Université Laval

Le CIRANO collabore avec de nombreux centres et chaires de recherche universitaires dont on peut consulter la liste sur son site web.

Les cahiers de la série scientifique (CS) visent à rendre accessibles des résultats de recherche effectuée au CIRANO afin de susciter échanges et commentaires. Ces cahiers sont écrits dans le style des publications scientifiques. Les idées et les opinions émises sont sous l'unique responsabilité des auteurs et ne représentent pas nécessairement les positions du CIRANO ou de ses partenaires.

This paper presents research carried out at CIRANO and aims at encouraging discussion and comment. The observations and viewpoints expressed are the sole responsibility of the authors. They do not necessarily represent positions of CIRANO or its partners. 


\title{
Why didn't the Global Financial Crisis hit Latin America?
}

\author{
Tjeerd M. Boonman ${ }^{*}$, Jan P.A.M. Jacobs ${ }^{\dagger}$, Gerard H. Kuper
}

\section{Résumé / Abstract}

Latin America has a rich history of financial crises. However, it was relatively unharmed by the 20072009 Global Financial Crisis (GFC). This paper investigates why, and in particular the role of commodity prices and its institutional framework - in line with the fourth generation financial crisis model. We set up Early Warning Systems (EWS) for Argentina, Brazil and Mexico. These consist of an ordered logit model for currency crises for the period 1990-2007 with a dynamic factor model to deal with the large number of explanatory variables. We present forecasts for the period 2008-2009.

We find that international indicators play an important role in explaining currency crises in Mexico, while banking indicators and commodities explain the currency crisis in Argentina and Brazil. Furthermore, debt and domestic economy indicators are relevant for Argentina and Mexico. Finally, we observe that currency crises in all three countries are related to institutional indicators. For none of the countries the Early Warning System would have issued an early warning for the GFC.

Mots clés/Keywords : Financial crises, Early Warning Systems, Latin America, dynamic factor models, ordered logit model.

Codes JEL/JEL Codes: C25, G01, N26

\footnotetext{
* University of Groningen, TEC de Monterrey, campus Guadalajara. Address for correspondence: Faculty of Economics and Business, University of Groningen, PO Box 800, 9700 AV Groningen, The Netherlands, email: t.m.boonman@rug.nl.

${ }^{\dagger}$ University of Groningen, CAMA, Australian National University and CIRANO.

${ }^{\sharp}$ University of Groningen.
} 


\section{Introduction}

The 2007-2009 global financial crisis has affected many countries including Latin America. In the fall of 2008 Latin American currencies depreciated sharply versus the US dollar (Brazil and Mexico depreciated by more than 40\%, Argentina by 20\%, see Figure 1), stock markets plunged (Argentina and Brazil by more than 50\%, see Figure 2), and spreads on yields surged (Argentina quadrupled, Mexico and Brazil doubled, see Figure 3). These dramatic changes did not trigger a financial crisis. The real economy contracted in 2009 in Mexico -influenza A-H1N1, recession in USA-, while Argentina and Brazil were hardly affected. The financial sector was not in danger at any time and no debt crises surged. The exchange rates returned relatively quickly to a level close to the pre-crisis situation, particularly in Brazil and Mexico.

Figure 1: Nominal exchange rates indexed $(2008 \mathrm{M} 1=100)$ for the period 2008-2009 for Mexico, Argentina and Brazil

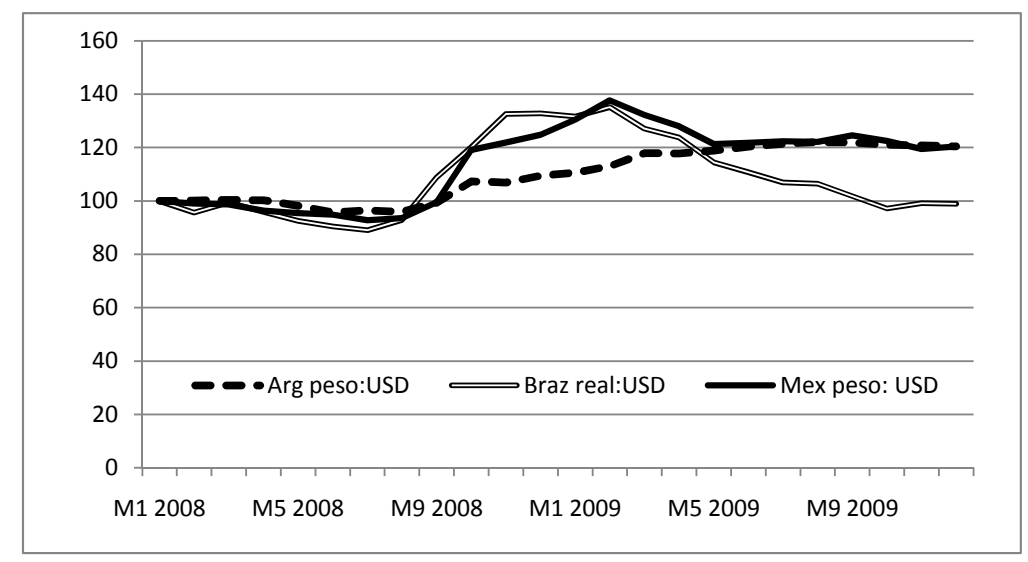

Would an Early Warning System have sent a warning? We address the question whether the countries have learned from their past experiences, which makes this study also relevant for other regions. Over time, various countries have experienced strong institutional changes in the form of structural reforms, or changes in political power (e.g. Mexico that saw PAN took over the presidency in 2000 after 70 years of continuous PRI governments). 
Figure 2: Stock market index for the period 2008-2009 for Mexico, Argentina and Brazil; $2008 \mathrm{M} 1=100$

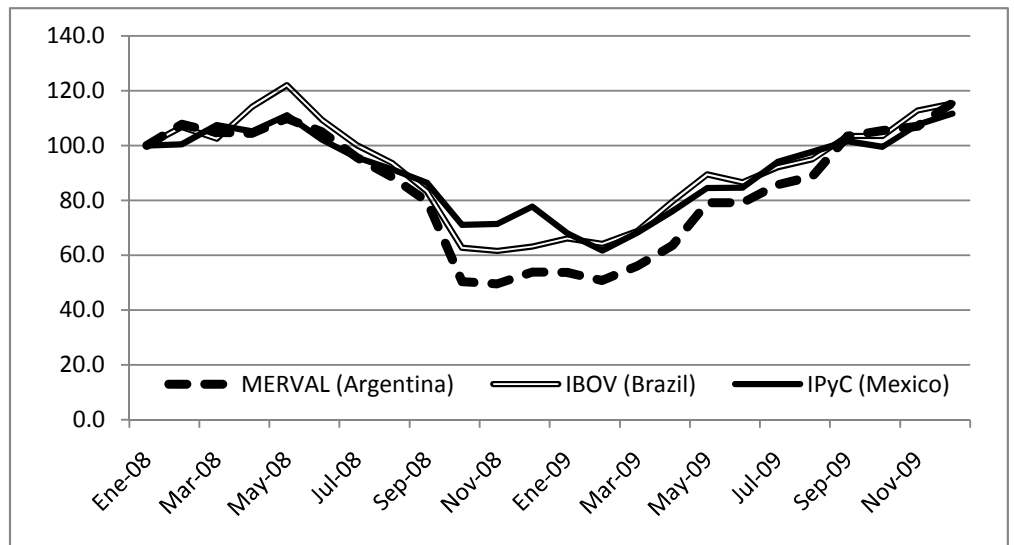

Figure 3: Sovereign bond interest rate spread for the period 2008-2009 for Mexico, Argentina and Brazil; basis points over US Treasuries

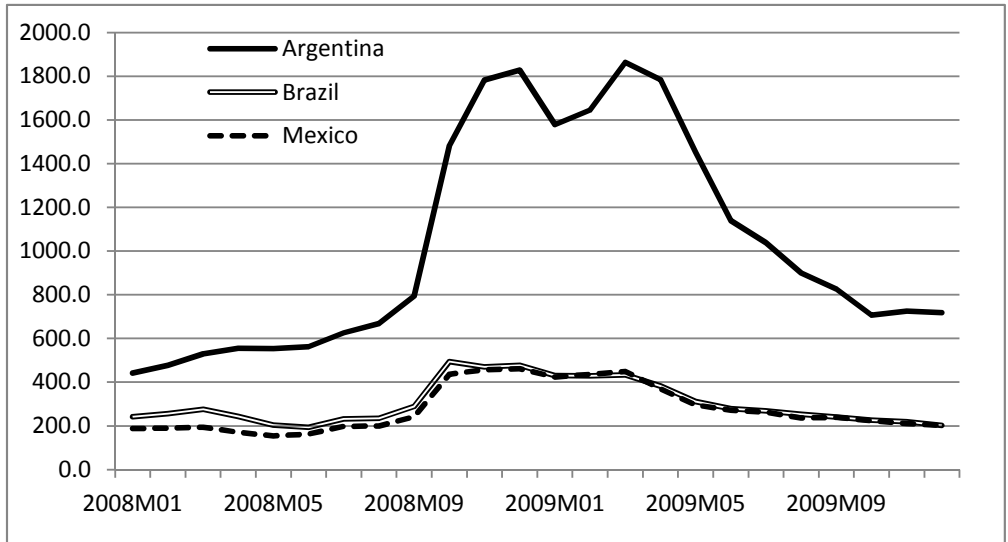


We confine attention in this paper on the three most important economies of Latin America: Argentina, Brazil and Mexico (LA-3). ${ }^{1}$ We focus on the period 1990 to 2009 because this period has essentially different characteristics than the 1970s and 1980s (hyperinflation, 1980s debt crisis, political system) and because of data availability. In addition, we only consider currency crises, and abstract from banking crises and debt crises.

Dating currency crises is not straightforward. We choose to measure currency crises as an ordered variable with responses ranging from 0 (for tranquil or non-crisis periods) to 3 (indicating a very deep crisis). We extend the crisis period by assigning the same value for both the month of crisis and the preceding six months. This has been done by e.g. Kaminsky (2006) and is justified since for the construction of early warning systems the run-up to the crisis is as important as the crisis itself.

We apply the ordered logit model using dynamic factor models to cope with the large number of crisis indicators. In that respect our paper is related to Cipollini and Kapetanios (2009), who also apply dynamic factors in their Early Warning System. They use the dynamic factor model of Stock and Watson (2002), and determine the number of factors and the number of lags on the basis of the information criteria of Bai and Ng (2002). We adopt the two-step framework of Doz, Giannone and Reichlin (2011), and use the criterion of Otter, Jacobs and den Reijer (2011) to determine the number of factors.

As explanatory variables we will use monthly series from 1990 to 2007 to analyze the three Latin American countries. Apart from the "usual suspects" - the common macroeconomic and financial variables - we also include institutional variables and commodityrelated indicators. Details on the explanatory variables are in Appendix A. We estimate the ordered logit models up to and including 2007, and forecast for 2008-2009.

We find that currency crises in Mexico are driven by international indicators, and to a lesser extent debt, by domestic economy and institutional indicators. Crises in Argentina

\footnotetext{
${ }^{1}$ The fourth economy, Chile, is not included because it has not experienced financial crises in the 1990-2009 period.
} 
are mainly related to banking and commodities, and to domestic economy and institutional indicators. Banking and commodities indicators dominate in the explanation of currency in Brazil; institutional indicators play a less important role. The fact that for all countries the institutional factors play a significant role supports the fourth generation financial crisis model. It also confirms previous work in which political indicators play a significant role in crisis forecasting (e.g. Bussière and Mulder 2000). For none of the three countries the Early Warning Systems would have issued a warning for the GFC.

The remainder of the paper is structured as follows. After a review of financial crises and models, early warning systems and empirical studies for Latin America in Section 2, Section 3 discusses the method. The data are presented in Section 4, followed by the empirical results in Section 5 and the analysis of out of sample performance in Section 6 . Section 7 concludes.

\section{Review}

\subsection{Four generations of crises and models}

Theoretical models for currency crises have been developed since the late 1970s, based on the seminal work of Krugman (1979). The characteristics of crises have changed over time and so have the models: the literature distinguishes four generations of financial crisis (models). The first generation models explain the crises as the result of fundamental inconsistencies in domestic policies, which at that time (1960s and 1970s) characterize the crises. The crises are preceded by a deterioration in the fundamentals, such as recurring budget deficits which are monetary financed, or persistent current account deficits which exhaust the foreign reserves.

With the crisis of the European Monetary System in 1992-1993 a second generation crisis appears, because the weak economic fundamentals alone could not explain such a 
dramatic drop in the exchange rate. Fundamentals still play a role: if these are very strong then no currency attack will take place, and if these are very weak then the government won't defend the currency. But when the fundamentals are in a "grey zone", multiple equilibria are possible. Relative small changes can have a big impact, which is known under the term "sunspot view". When speculators suspect that the government is not committed to defend the exchange rate (e.g. for restoring international competitiveness), then a massive currency attack follows which can trigger a self-fulfilling devaluation (see Obstfeld, 1996).

The Asian crisis of 1997-1998, a third generation crisis, gave a new boost to crisis research. Banks and financial institutions expand and ease their loan granting policies prior to the crisis, because they count on a government bailout in case of solvency problems. This moral hazard behaviour leads to an excessive build-up of external private debt followed by a collapse (see McKinnon and Pill, 1997). A currency devaluation can trigger a banking and debt crisis when banks and government have a mismatch in the balance sheet: domestic assets financed by foreign liabilities (see Chang and Velasco, 1998). Krugman (2003) adds that a combination of factors such as panics in the international investment community, policy mistakes in handling the crisis and poorly designed international rescue programs cause a financial panic which results in currency crises, runs on banks, massive bankruptcies and political turmoil.

The development of fourth generation models of financial crises is still under way. Breuer (2004) refers to a model in which crises are determined by institutional factors. Poor institutional factors are the underlying cause for unsustainable policies, excessive borrowing and lending, hyperinflation, etc. Although economic factors also play a role in the fourth generation models, the institutional factors set the conditions for economic outcomes. Many databases that quantify institutional factors have become available recently, enabling more research. 


\section{$2.2 \quad$ Early Warning Systems}

Early Warning Systems (EWS) are models that send signals or warnings well ahead in time of a potential financial crisis. The dozens of EWS that have been developed differ widely in the definition of a financial crisis, the period of estimation, data frequency and the countries included in the database, the inclusion of indicators, the forecast horizon and the statistical or econometric method (Jacobs, Kuper and Lestano, 2008). For an overview see Kaminsky, Lizondo and Reinhart (1998) and Abiad (2003). Most studies use binary methods (logit or probit), the signals approach, Ordinary Least Squares, Markov Switching models, binary recursive trees, contingent claims analysis or a combination of these methods.

The typical EWS model is applied to a large number of emerging countries from all over the world - in order to obtain sufficient crisis observations. This approach has received criticism. To quote Abiad (2003): "The one-size-fits-all, panel data approach used in estimating most Early Warning Systems (EWS) might be one of the causes of their only moderate success". Kaminsky (2006) confirms this and Beckmann, Menkhoff and Sawischlewski (2006) also suggest that differences between geographical regions justify a regional approach. A growing number of studies focuses on a geographic region-particularly South East Asia and Central Europe and Latin America. Even within a region distinctions can be made. Van den Berg, Candelon and Urbain (2008) construct country clusters for six Latin American countries. In this study for the period 1985-2004, Argentina, Brazil and Peru are grouped in one cluster because of similar inflation patterns, while Mexico, Uruguay and Venezuela are grouped in the other cluster, due to important privatizations in the early 1990s. 


\subsection{Empirical studies for Latin America}

With its rich history of financial crises (Reinhart and Rogoff 2009), Latin American countries - particularly Argentina, Brazil and Mexico-have been included in EWS models applied to emerging economies from all over the world. There are also studies with an exclusive focus on the region. Kamin and Babson (1999) use a binomial probit model with Vector AutoRegressions to distinguish between external and internal factors, to predict financial crises. They use panel data for six Latin American countries, for the period 1981-1998. Herrera and Garcia (1999) group the indicators into a composite index, to analyze the indicators jointly. As in the signals approach, they set thresholds which indicate financial crises. They apply their model to eight Latin American countries. Argentina's long history of currency and other financial crises is analyzed in studies such as Alvarez Plata and Schrooten (2004), Kaminsky, Mati and Choueiri (2009) and Cerro and Iajya (2009). Another crisis that has been researched widely is the Mexico 1994/1995 "tequila" crisis. Sachs, Tornell and Velasco (1996) focus on contagion, whereas Beziz and Petit (1997) study the use of real time data on predicting the crisis.

\section{Method}

We first apply dynamic factor models to extract the factors from the indicators, and then use the estimated factors as regressors in the ordered logit model, with a crisis dating dummy as dependent variable.

\subsection{Factor models}

In factor models an observable set of $n$ variables is expressed as the sum of mutually orthogonal unobservable components: the unobservable common component (factors) and the unobservable idiosyncratic component. The constructed factors are independent from 
each other, which means maximum information with a minimum number of factors in the model. The primary reason for the popularity of factor models is that one can include a large number of variables and let the model reduce this into a much smaller number of factors $(n>>r)$. This is a desirable feature since more data have become available for policy makers and researchers at a more disaggregated level. The drawback of using factor models to explain the occurrence of financial crises is the difficulty of interpretation - and sometimes unexpected signs - that can be placed upon the factors that explain financial crises.

Different types of factor models are distinguished: exact and approximate, static and dynamic. When the factors and the idiosyncratic components are uncorrelated and i.i.d., then the model is static, exact, or strict. Exact factor models can be consistently estimated by maximum likelihood. However the restrictions on the model are often not met in empirical applications. When the number of variables goes to infinity, the correlation restrictions of the exact factor model can be relaxed and one can use the approximate factor model. In the static, approximate factor model the idiosyncratic components are (weakly) correlated, which covers cross-correlation and heteroskedasticity between the idiosyncratic errors and correlation between the common components and the idiosyncratic components (see e.g. Barhoumi, Darné and Ferrara 2010).

Whereas static factor models only consider cross-sectional relations, the dynamic factor model also takes into account lags and leads. Most dynamic factor models are approximate. The dynamic factor model has the advantage that it takes into account both current and temporal relationships, which makes it - in theory - superior to the static model. However, empirical evidence is mixed. Barhoumi et al. (2010) for example conclude that dynamic factor models with a large number of variables do not necessarily produce better forecasting results of French GDP than static models with a small number of variables. Schumacher (2007) also mentions a number of studies with mixed empirical success for the dynamic 
factor model.

\section{Static factor models}

The static factor model has the following form:

$$
X_{i, t}=\lambda_{i, 1} f_{1, t}+\lambda_{i, 2} f_{2, t}+\ldots+\lambda_{i, r} f_{r, t}+u_{i, t}=\Lambda f_{t}+u_{t}
$$

where $\Lambda$ is an $(n \times r)$ matrix of factor loadings, $f_{t}$ is an $(r \times 1)$ vector of factors in period $t, i=1, \ldots, n$ and $t=1, \ldots, T$. The assumptions for the exact static factor model are: $\mathrm{E}\left(u_{t}\right)=0, \mathrm{E}\left(u_{t} u_{t}^{\prime}\right)=\Sigma=\operatorname{diag}\left(\sigma_{1}^{2}, \sigma_{2}^{2}, \ldots, \sigma_{N}^{2}\right), \mathrm{E}\left(F_{t} u_{t}^{\prime}\right)=0$ and for the factors: $\mathrm{E}\left(f_{t}\right)=0, E\left(f_{t} f_{t}^{\prime}\right)=\Omega_{f}$

The principal components method is used to estimate the factors. The principal components of $X_{t}$ are the factors:

$$
F_{t}=S^{\prime} X_{t}=\left(S_{1} S_{2} \ldots S_{r}\right)^{\prime} X_{t}
$$

where the factor estimates $F_{t}$ are the first $r$ principal components of $X_{t}$, and $S_{j}, j=1, \ldots, r$, are the eigenvectors that correspond to the $r$ largest eigenvalues.

\section{Dynamic factor models}

The dynamic factor model extends the static factor model by also taking into account correlations over time

$$
X_{t}=A_{0} f_{t}+A_{1} f_{t-1}+\ldots+A_{p} f_{t-p}+\epsilon_{t}
$$

where $x_{t}$ is the $N \times 1$ vector of observations of explanatory variables in period $t$. The variables are stationary, demeaned and standardize; $f_{t}$ is the $r \times 1$ vector of common 
components or factors. For a review of dynamic factor models we refer to Stock and Watson (2011).

Dynamic factors can take several forms. Stock and Watson (1998) allow for time varying loadings, but do not allow for autoregressive dynamics. Forni, Hallin, Lippi and Reichlin (2005) adopt a different definition, which is christened a static factor representation of the DFM by Stock and Watson (2005) and a pseudo DFM by Kapetanios and Marcellino (2009)

$$
X_{t}=A F_{t}+\epsilon_{t}
$$

where $A \equiv\left[\begin{array}{llll}A_{0} & A_{1} & \ldots & A_{p}\end{array}\right]$ and $F_{t} \equiv\left[f_{t}^{\prime} \ldots f_{t-p}^{\prime}\right]^{\prime}$. Hence, a dynamic factor model with $r$ common factors can be written as a static factor model with $(p+1) r$ static factors.

The dynamics of the $r$ common factors is represented by a vector autoregressive $\operatorname{VAR}(m)$ process of order $m$

$$
F_{t}=\Gamma(L) F_{t}+\nu_{t}
$$

where $\Gamma(L) F_{t}=\Gamma_{1} F_{t-1}+\ldots+\Gamma_{m} F_{t-m}$ and $\nu_{t} \sim N\left(0, \Sigma_{\nu}\right)$.

The factors can be estimated in the frequency domain (Forni et al., 2000, 2002), by principal components (Bai and Ng, 2002; Stock and Watson, 2002a, 2002b), or by principal components in combination with the Kalman filter (Forni et al. 2009; Doz, Giannone and Reichlin, 2011, henceforth DGR). In this paper we employ the two-step approach of DGR. In the first step preliminary estimates of the factors and estimates of the parameters of the dynamic factor models are computed by a principal components analysis. In the second step the factors are updated via the Kalman smoother. DGR use a slightly different version of the static factor representation of the dynamic factor model, without dynamics, in the measurement equation of their state space form, in combination with a $\operatorname{VAR}(p)$ for the 
common factors in companion form as state equation

$$
\begin{gathered}
X_{t}=\left(\begin{array}{ccc}
A_{0} & 0 & \ldots 0
\end{array}\right)\left(\begin{array}{l}
f_{t} \\
f_{t-1} \\
\vdots \\
f_{t-p+1}
\end{array}\right)+\epsilon_{t} \\
\left(\begin{array}{l}
f_{t} \\
f_{t-1} \\
\vdots \\
f_{t-p+1}
\end{array}\right)=\left(\begin{array}{ccccc}
A_{1} & A_{2} & \ldots & A_{p-1} & A_{p} \\
I_{r} & 0 & \ldots & 0 & 0 \\
0 & I_{r} & \ldots & 0 & 0 \\
\vdots & \vdots & \ddots & \vdots & \\
0 & 0 & \ldots & I_{r} & 0
\end{array}\right)\left(\begin{array}{l}
f_{t-1} \\
f_{t-2} \\
\vdots \\
f_{t-p}
\end{array}\right)+\left(\begin{array}{l}
I_{r} \\
0 \\
\vdots \\
0
\end{array}\right) \nu_{t} .
\end{gathered}
$$

\section{Determination of the number of factors}

One of the issues in factor analysis is the determination of the optimal number of factors. Various procedures have been proposed, e.g. the Bayesian Information Criterium, the Kaiser Criterium and Cattell's scree test. The number of factors is better overestimated than underestimated, because the factors are still estimated consistently if the number of factors is overestimated (Breitung and Eickmeier, 2006).

With the large dimensional factor models of recent years many studies have proposed solutions and consistent estimators for the number of factors using different factor model and distributional assumptions. See e.g. Bai and Ng (2002, 2007), Amengual and Watson (2007), Kapetanios (2010), Hallin, and Liška (2007), Harding (2009), Jacobs and Otter (2008), and Onatski (2009). Here we employ the criterion of Otter, Jacobs and Den Reijer (2011), which is associated with Onatski's (2009) test statistic, and related to the scree test. 


\section{Interpreting the factors}

Using factor models comes at a cost. Determining the economic relevance of factors and interpreting the factors in a meaningful way is problematic. The factor loadings can be used to assign a label to each of the common factors. This is a good strategy for static factors, but for dynamic factors it is cumbersome. Here we look at correlations between dynamic factors and the indicators (following e.g. Breitung and Eickmeier, 2006). ${ }^{2}$

Interpreting estimation results using factors as dependent variables needs to be done with great care. Most indicators feature in more than one factor, so focusing on a single factor only partially explains the full impact of an indicator on the probability of a crisis, and may even lead to unexpected results.

\subsection{Crisis dating}

Identifying and dating currency crises has been debated since the mid 1990s. Two approaches can be distinguished: the successful attack approach and the speculative pressure approach. In this study, we opt for the speculative pressure approach, which was initialized by Eichengreen, Rose and Wyplosz (1995). In this approach we distinguish events from crises to identify and date currency crises. Events consist of significant changes in exchange rate arrangements, such as official decisions to float or fix the exchange rate, to widen the fluctuation band, etc. Crises consist of periods in which the exchange rate comes under speculative attack. The set of crises periods is not a subset of the set of events. For example, when the exchange rate arrangement is not preceded by a significant exchange market pressure, then this is not considered as a crisis. Also the set of events does not include the set of crises. For example, when a speculative attack is unsuccessful so that there is no realignment of exchange rates, then it is not an event, but it is considered a

\footnotetext{
${ }^{2} \mathrm{An}$ alternative is to place the set of variables in well-defined groups, and apply factor analysis to each of the groups. Obviously, the factors derived in this way are no longer orthogonal.
} 
crisis. In other words, also unsuccessful attacks should be considered a crisis. A currency attack can be unsuccessful when it is successfully defended by the monetary authorities through the use of international reserves, by increasing the interest rates or by restricting transactions in foreign currency.

The speculative pressure index, or the Exchange Market Pressure Index (EMPI), is defined as a weighted average of exchange rate changes, changes in the international reserve and changes in the interest rates. A crisis is identified if the index exceeds an upper bound. We follow the modified definition of Kaminsky and Reinhart (1999) and Kaminsky (2006): the weighted average of exchange rate changes and reserve changes, with weights such that the two components of the index have equal conditional volatilities. Periods with hyperinflation are excluded from the periods without hyperinflation: for each subcategory an index is constructed and threshold exceedances determined. To determine the crises we deviate from Kaminsky and Reinhart (1999), who identify a crisis when the observation exceeds the mean by more than three standard deviations. We maintain this definition to identify "very deep" crises. Following Cerro and Iajya (2009) we extend the definition of crises by introducing "deep" crises (two adjacent months with exceedance between 2 and 3 times the standard deviation) and "mild" crises (two adjacent months with exceedance between 1 and 2 times the standard deviation). The ordinal variable that indicates crises periods is constructed as follows: the value 0 indicates no crisis periods, the value 1 is assigned to mild crises, 2 to deep crises and 3 to very deep crises. As is common in early warning systems of currency crisis, we will use the same dummy variable for the crisis entry month and the run-up to the crisis. In this paper we choose a period of six months preceding the crisis entry. In case a crisis follows within six months upon a crisis, then the second crisis is considered a continuation and is eliminated. If types of crises overlap we assign the highest ordinal number to that crisis. 


\subsection{Ordered logit model}

As our dependent variable can only take four values $(0=$ no crisis; $1=$ mild crisis; $2=$ deep crisis, and $3=$ very deep crisis), we employ an ordered choice model, which extends the binary choice model, allowing for a natural ordering in the outcomes $y$. Assume that there are $N+1$ possible outcomes, then

$$
y=\left\{\begin{array}{l}
0 \text { if } y^{*} \leq \mu_{1}, \\
1 \text { if } \mu_{1}<y^{*} \leq \mu_{2}, \\
2 \text { if } \mu_{2}<y^{*} \leq \mu_{3} \\
\vdots \\
N \text { if } \mu_{N}<y^{*},
\end{array}\right.
$$

where $y$ is the observed ordinal variable, and $y^{*}$ is the continuous latent variable that is equal to

$$
y^{*}=Z=\alpha+\beta X
$$

The limits $\mu_{i}$ separate the various outcomes, and are estimated simultaneously with the parameters $\alpha$ and $\beta$.

We use the ordered logit model, because the logistic distribution (logit model) has wider tails than the normal distribution (probit model). This is preferable if an event has a very low frequency, as is the case in financial crises (Manasse, Roubini and Schimmelpfennig 
2003). The probabilities for each of the outcomes are:

$$
\begin{aligned}
P(y=0) & =\frac{1}{1+e^{-\left(Z-\mu_{1}\right)}}, \\
P(y=1) & =\frac{1}{1+e^{-\left(Z-\mu_{2}\right)}}-\frac{1}{1+e^{-\left(Z-\mu_{1}\right)}}, \\
& \vdots \\
P(y=N) & =1-\frac{1}{1+e^{-\left(Z-\mu_{N}\right)}} .
\end{aligned}
$$

Interpretation of the parameters in an ordered choice model is not trivial (see Kennedy, 2008, pp.258-259 and the references therein). Kennedy suggests to omit the intercept $\alpha$ to facilitate interpretation. One way to interpret the outcomes is by calculating the ratio of two parameter estimates, i.e, the relative change in one explanatory variable to compensate for a change in another explanatory variable.

\section{Data}

Our sample starts in the early 1990s, when the effects of last spillovers of the 1980s Latin American debt crisis faded away. The analysis for Argentina starts after the introduction of the Convertibility Plan (April 1991) and for Brazil after the introduction of the Real Plan (July 1994), which both can be regarded as a structural break with the hyperinflation periods. Mexico did not experience any period of hyperinflation in the 1990s.

To identify currency crises we follow the EMPI definition of Kaminsky (2006), but take into account the severity of the crisis. We categorize the severity of crises as mild, deep and very deep. Very deep crises are rare; each of the countries under investigation experienced only one very deep crisis in the in-sample period: Mexico (December 1994), Brazil (January 1999) and Argentina (January 2002). Figures 4, 5 and 6 show the crisis observations. 
Figure 4: Actual crisis dates for Argentina for the period 1991-2007

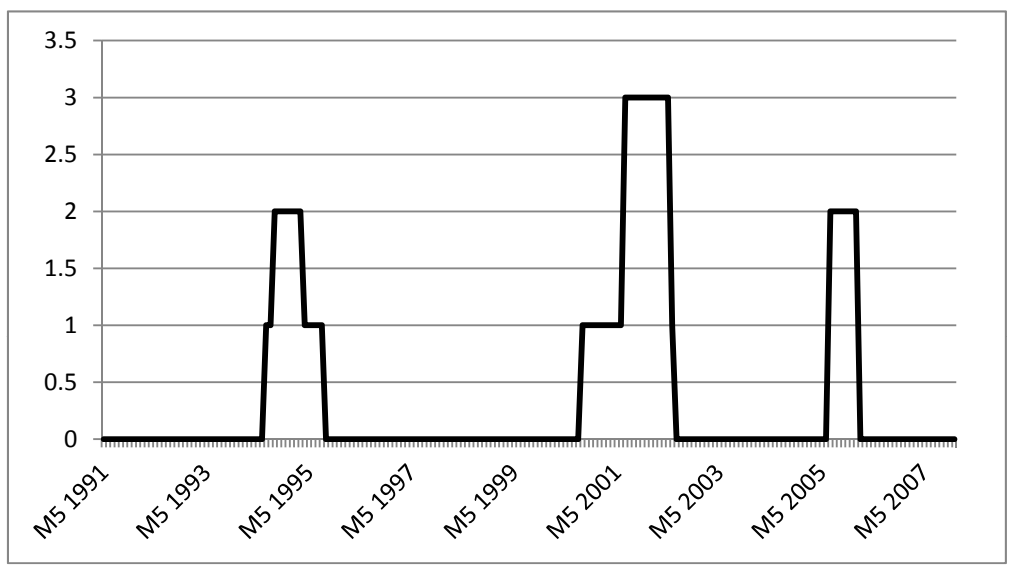

Figure 5: Actual crisis dates for Brazil for the period 1994-2007

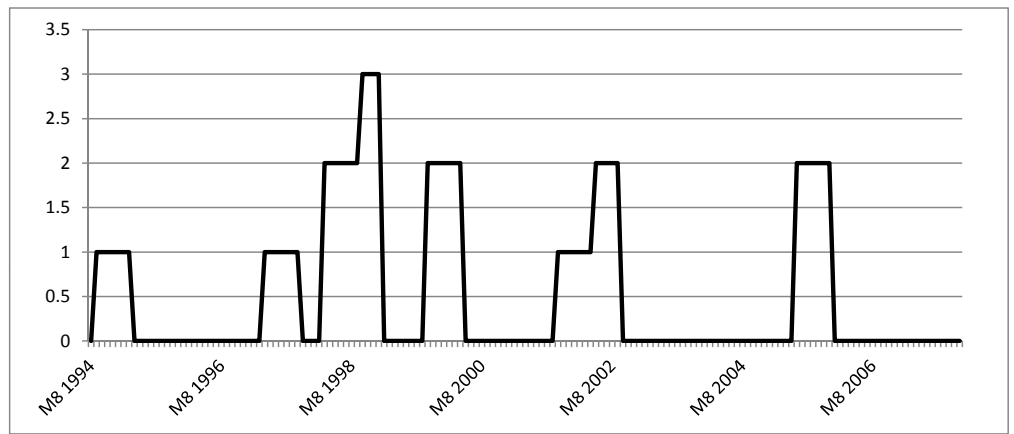

Figure 6: Actual crisis dates for Mexico for the period 1990-2007

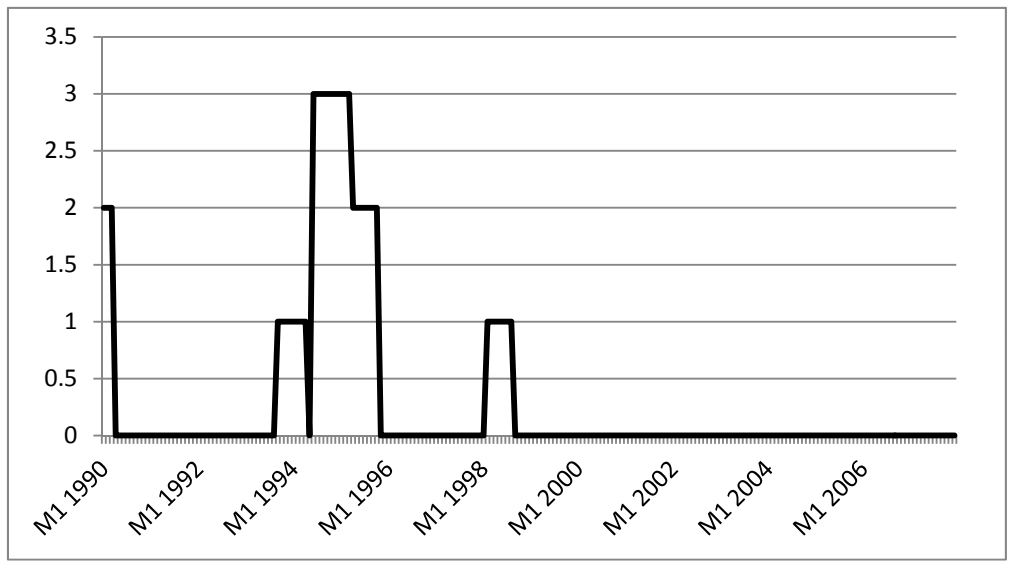


For the explanatory variables we select series based on three criteria: (i) series have to be complete, i.e. no missing observations; and (ii) series have to be used in the literature. There are however some data limitations. Not all time series are sufficiently long which limits the selection of explanatory variables. Another challenge is the mixed frequency of the time series. The selected series can be classified into separate categories:

- 13 external economic indicators, among which the deviation from the trend of the real exchange rate, exchange rate volatility, growth of exports, imports and foreign reserves, import cover, ratio of M2 to foreign reserves. Source: IFS (IMF).

- 16 domestic economic indicators, among which domestic real interest rate, inflation, M2 multiplier, industrial production. Source: IFS.

- 16 institutional indicators, among which election dates, Herfindahl indices, political stability, corruption. Sources: ICRG, DPI.

- 10 debt indicators, among which total debt, short term debt, debt service, arrears. Sources: WDI/GDF (World Bank).

- 25 banking sector indicators for Argentina (14 for Brazil and Mexico), among which credit to public sector, to private sector, ROE, deposits. Sources: Financial Structure (World Bank), WDI/GDF, IFS.

- 7 global and financial markets indicators, among which economic growth in world, US yield, share market index returns, bond yield country spread. Sources: IFS, GEM (World Bank), Economatica.

- 12 commodity related indicators, among which prices of oil, metals, agricultural products, exports and imports of fuel, agricultural products, food and metals. Sources: IFS, WDI/GDF. 
For a complete overview, including definitions and transformations, we refer to Appendix A.

The series have been tested for non-stationarity (using Augmented Dickey-Fuller tests) and visually inspected for seasonal effects. Where necessary a transformation was made to render them stationary. To deal with mixed frequencies in series, we apply simple quadratic interpolations. All series are normalized, i.e. demeaned and divided by its sample standard deviation.

\section{Empirical results}

We estimate the ordered logit model for Argentina, Brazil and Mexico for the period up to and including 2007, and we forecast for the 2008-2009 period. In this section we discuss both the dynamic factor model outcomes and correlations with individual indicators, and the estimation results for the ordered logit models. ${ }^{3}$

\subsection{Argentina}

The criterion of Otter, Jacobs and Den Reijer (2011) suggests 11 factors for Argentina. When focusing on the variables with the largest correlation (positive or negative) we can label each factor. ${ }^{4}$ Here we give special emphasis to institutional and commodity-related indicators:

- Factor 1 is strongly correlated with banking and commodity indicators. The banking indicators consist of credit granting and profitability variables and are positively and negatively correlated with this factor. The commodity indicators are primarily related to agriculture and food exports; all are negatively correlated with

\footnotetext{
${ }^{3}$ For all three countries we also employed static factors as regressors in the ordered logit models and found that differences were marginal. See Appendix C.

${ }^{4}$ The complete list of factors with the ten indicators with highest correlation can be found in Appendix B.
} 
the factor, which implies that an increase in commodity exports leads to a lower factor.

- Factor 2 is dominated by domestic economic indicators. Economic growth and savings are negatively correlated with the factor, the real interest rate and the M2 multiplier are positively correlated with the factor.

- Factor 3 is a mixed factor as it does not have any dominating category. Some indicators stand out for their high correlation with the factor. This applies to the T-bill and the return in the US market.

- Factor 4 is dominated by banking and debt indicators and complemented by institutional indicators (bureaucratic quality and government stability - these enter with opposite signs into the factor).

- Factor 5 can be labelled the institutional factor. These indicators are negatively correlated with the factor.

- Factor 6 is strongly correlated with banking and external economic indicators. The banking indicators are mainly credit granting variables while the external economic indicators are related to imports.

- Factor 7 is-like factors 1 and 4-associated with banking indicators.

- Factor 8 is a mixed factor as it does not have any dominating category.

- Factor 9 is influenced mainly by commodity and debt indicators. The commodity indicators are related to imports and are negatively correlated with the factor.

- Factors 10 and 11 are very diverse. The variables have low correlations with the factor 


\section{Estimation results}

The dynamic factor combination which yields the best fit in the ordered logit model has 4 dynamic factors and 2 lags. Appendix $\mathrm{C}$ shows that factors 4, 6 and 8 are not significant at a $5 \%$ significant level. Factors 2 and 9 increase the probability of a crisis. The adjusted pseudo $\mathrm{R}^{2}$ is 0.705 and the fit is shown graphically for the in-sample period 1991-M5 to 2007-M12 in Figure 7.

Figure 7: Actual and fitted data, and the residuals form the ordered logit model for Argentina for the period 1991-2007

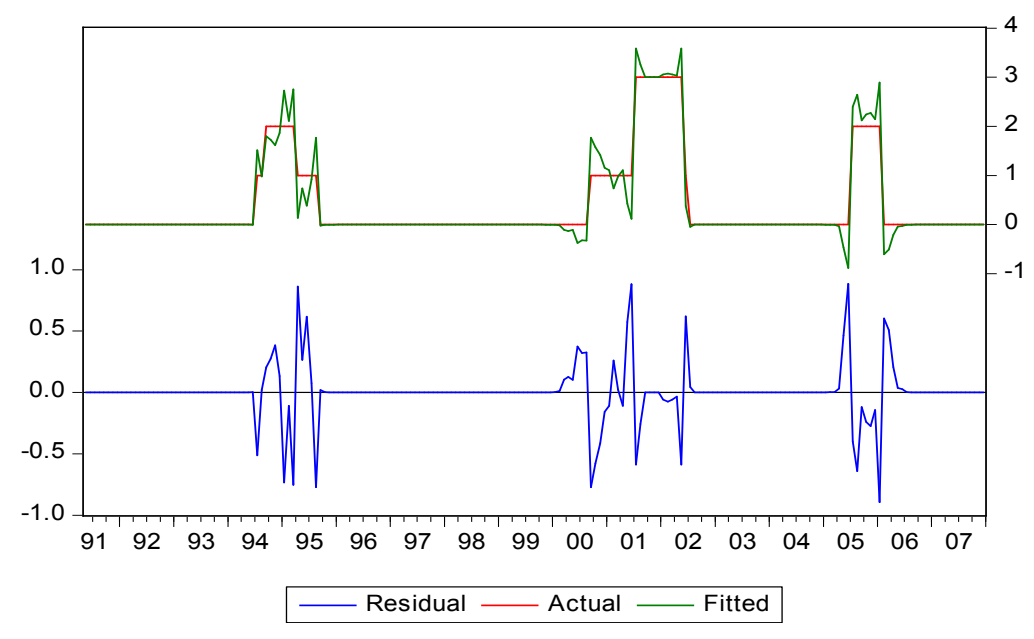

Interpreting the outcomes in terms of the underlying indicators is not trivial, as we argued above. Nevertheless, it can be seen that banking indicators and, to a lesser extent, debt and domestic economy indicators play an important role in the explanation of currency crises. In the following, we focus on commodities prices (factors 1 and 9) and institutions (mainly factor 5) only.

Factors 1 and 9 have opposite signs in the ordered logit model. Although this may seem contradictory at first sight, this is not so if we realize what each factor contains: factor 1 consists of commodities exports indicators (negative correlation), while factor 9 consists of commodities imports indicators (negative correlation). Increasing exports lead 
to a decrease in factor 1 which is associated with a higher probability of a currency crisis. Increasing imports lead to a decrease in factor 9 which is associated with a lower probability of a currency crisis. In other words, in the run-up to the crisis the exports of commodities increase and the imports of commodities decrease. A plausible explanation is the need for foreign currency to relieve the pressure on the exchange rate to depreciate.

With respect to the role of institutions we arrive at the unlikely conclusion that better institutions (negatively correlated with factor 5) increase the probability of a crisis (negative sign in the ordered logit model). To identify the importance of the institutional indicators we re-estimated the model without institutional variables. The results, reported in Appendix C, show that the fit worsens; the adjusted pseudo $\mathrm{R}^{2}$ decreases from 0.70 to 0.47. In addition, the re-estimated model overestimates the crises probabilities: mild and deep crises come out as deep and very deep crises, respectively.

We conclude that both commodities and institutional indicators play an important role in many of the factors, and by this have an impact on crisis probabilities. Furthermore, banking sector and, to a lesser extent, debt and domestic economy indicators play important roles in the explanation of currency crises.

\subsection{Brazil}

The criterion of Otter et al. (2011) suggests 9 factors for Brazil. The complete list of factors and the ten indicators with strongest correlations can be found in Appendix B.

- Factor 1 consists of a wide range of indicators, without any dominating category.

- Factor 2 is dominated by banking indicators, primarily related to credit granting. All indicators are negatively correlated with the factor, so an increase in the indicator leads to a lower value of the factor.

- Factor 3 consists of a wide range of indicators, without any dominating category. 
- Factor 4 is associated with commodities and global indicators. Commodities primarily contain commodities imports (negative correlation) and global indicators are associated with global economic growth (negative correlation).

- Factor 5 is dominated by institutional and commodities indicators. Two of the three institutional indicators are negatively correlated with the factor. Agriculture is strongly, negatively correlated with this factor, implying that an increase in the value added by agriculture sector implies a decrease in the factor.

- Factor 6 is dominated by commodities and institutional indicators. While agriculture imports and the petroleum price are positively correlated wit the factor, fuel exports are negatively correlated. The institutional indicators are related to the economic and investment state. Both institutional indicators are negatively correlated with the factor.

- Factor 7 is related to institutional and external economic indicators. The external economic indicators are all related to the foreign reserves. The institutional factors have a political character. More concentrated government (higher Herfindahl index) and a more disperse opposition are related to a higher factor, while improved law and order leads to a lower factor.

- Factor 8 is dominated by bank indicators.

- Factor 9 is mixed. The correlations with the factor are very low.

\section{Estimation results}

The combination of 3 dynamic factors and 2 lags yields the best fit in the ordered logit model for Brazil. We add two dummy variables: to identify an election year (elections for the executive power) and contagion (a currency crisis in one of the other two countries). 
The ordered logit results are presented in Appendix C. Factors 1, and 7 are not significant at the $5 \%$ significant level. Also the dummy variables are not significant. Factors 4 and 6 lower the probability of a crisis. The adjusted pseudo $\mathrm{R}^{2}$ for the DFM is 0.225 and the fit is shown graphically for the in-sample period 1994-M8 to 2007-M12 in Figure 8. We can observe in the graph that the model overestimates crises events and underestimates crisis recovery periods, which explains the relatively low adjusted pseudo $\mathrm{R}^{2}$. Since we are interested in crisis events, the over- and underestimation is not much of a worry - we care more about a correct timing.

Figure 8: Actual and fitted data, and the residuals form the ordered logit model for Brazil for the period 1994-2007

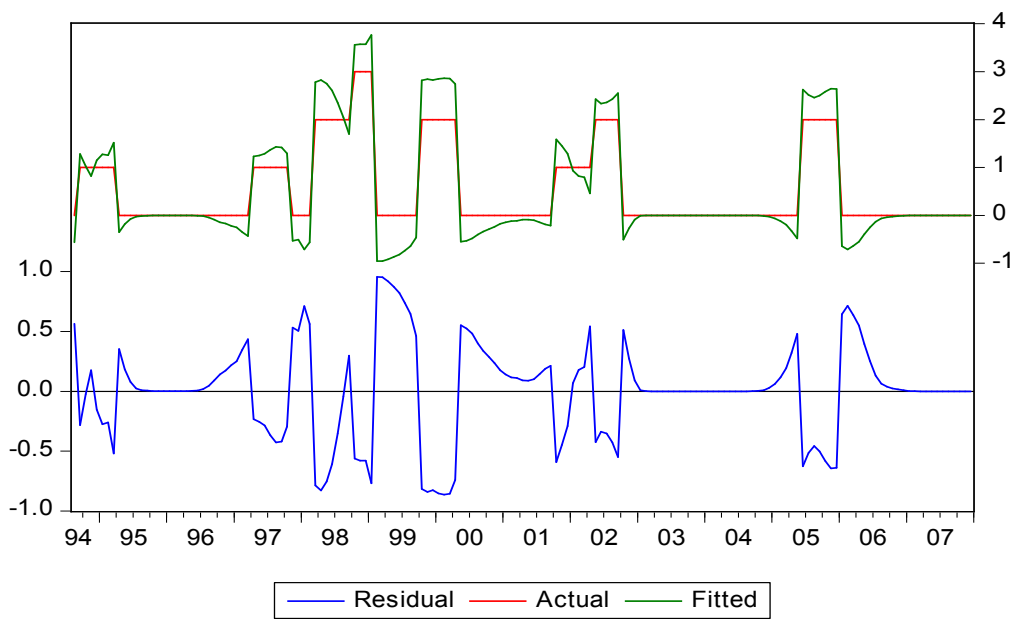

Banking sector indicators enter all factors. This shows the importance of the sector for the occurrence of currency crises. Domestic economic factors seem to play a minor role.

Factors 4, 5, and 6 (related to commodity prices) show ambiguous signs in the ordered logit model. Factor 4 consists of commodities imports indicators. An increase in commodities imports is associated with a higher probability of a currency crisis. From factor 5 we can derive that with increasing food exports and increasing value added by the agriculture sector the probability of a crisis decreases. Combining the effect, we can observe that in the run-up to a crisis commodities imports increase and food exports decrease. Under a 
fixed exchange rate regime where prices are not adjusted through the exchange rate, the imports become relatively cheap and exports relatively expensive. This situation is not sustainable and will culminate into a devaluation of the currency. Factor 6 has opposite signs and does not fit in this mechanism.

The institutional factors show a mixed picture: an improvement in bureaucratic quality, democratic accountability and internal conflict is associated with a lower probability of a crisis. However, this relation is not followed in improvements in the law and order situation and in the non-political institutional indicators (socio-economic circumstances, investment profile). The Herfindahl indices seem to indicate that governments which consist of less political parties have a higher probability of crises.

We conclude that the probability of a currency crisis in Brazil is mainly influenced by commodities, banking and institutional indicators. In contrast with Argentina and Mexico, the important categories in Brazil are limited to these three categories only.

\subsection{Mexico}

According to the criterion of Otter et al. (2011) the number of factors for Mexico is 7. The complete list of factors with the ten indicators which have the strongest correlation can be found in Appendix B.

- Factor 1 is dominated by commodities indicators and to a lesser extent by banking and external economic indicators. The commodities consist of both exports and imports, yet all indicators have the same negative correlation in this factor.

- Factor 2 is strongest correlated with debt and economic domestic indicators. All debt indicators are negatively correlated with the factor. The two commodities indicators are exports related to agriculture and food; both show a negative correlation with the factor. 
- Factor 3 is a mixed factor and consists of banking, domestic economic and institutional indicators. Both institutional indicators are negatively correlated with the factor. The other categories have positive and negative correlations with the factor.

- Factor 4 consists of external economic and global indicators and is complemented by institutional indicators. The indicators are related to imports, economic growth in the USA and interest rates in the USA. Given the fact that Mexico's largest trading partner is the USA, this strong correlation should not come as a surprise. The institutional indicators show positive and negative correlations with the factor.

- Factor 5 consists of a wide range of indicators, without any dominating category.

- Factor 6 is dominated by banking indicators, which all show the same (negative) correlation with the factor.

- Factor 7 has low correlations with the factor and should therefore be interpreted with caution. The categories that dominate are external economic and global indicators.

\section{Estimation results}

The combination of 3 dynamic factors and 2 lags yields the best fit in the ordered logit model for Mexico. As in the model for Brazil we add two dummy variables to identify an election year and to include contagion. Appendix $\mathrm{C}$ presents the estimation results. Factors 1,5 and 6 are not significant at the 5\% significant level; factors 2 and 3 lower the probability of a crisis. The contagion dummy variable is not significant. The adjusted pseudo $\mathrm{R}^{2}$ is 0.558 and the fit is shown graphically for the in-sample period 1990-M1 to 2007-M12 in Figure 9.

The categories that dominate the factors are external economy and global indicators. 
Figure 9: Actual and fitted data, and the residuals form the ordered logit model for Mexico for the period 1990-2007

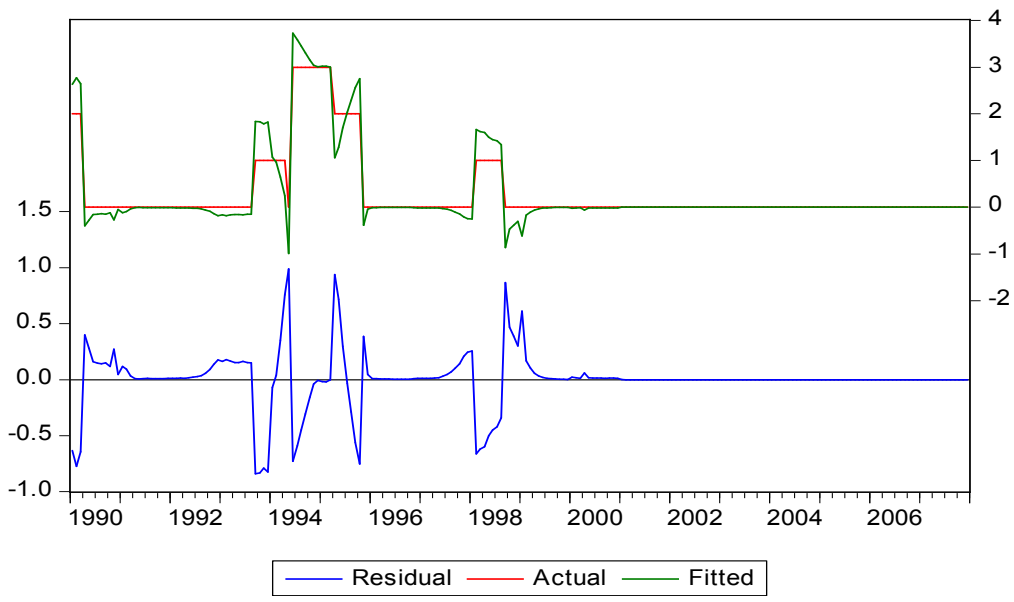

Other important categories are the banking sector, domestic economy indicators and institutional indicators.

Commodities are mainly represented in factor 1 , and to a lesser extent in factor 2 . Factor 1 is not significant at the $5 \%$ level. The interpretation of this estimate would have been hard because the correlations of all indicators with the factor is negative while we expect to see a difference between exports and imports. The two commodity indicators in factor 2 are related to exports and are negatively correlated with the factor. This implies that an increase in the commodities exports will decrease factor 2 , which will increase the probability of a crisis. In other words, in the run-up to a crisis the exports of commodities increase. A plausible explanation is the need for foreign currency to relieve the pressure on the exchange rate to depreciate.

Institutional indicators do not dominate any factor, but are present in factors $3,4,6$ and 7. The relations with factors and crises are ambiguous.

We conclude that the probability of a currency crisis in Mexico is mainly influenced by external economy and global indicators, which confirms the importance of international trade, in particular with its main trade partner, the USA. Domestic economy, debt and 
institutional indicators are less important in the explanation of currency crises. Contrary to Argentina and Brazil, neither commodities nor banking indicators play an important role in the explanation of currency crises in Mexico.

\section{Out of sample performance}

In this section we test the performance of the estimated model out of sample. We extrapolate the dynamic factors, with simple ARMA processes, and forecast the probabilities of a mild, deep and very deep crisis in the period 2008-2009.

\section{Argentina}

The forecasts under the dynamic factor model extrapolation results in a $100.0 \%$ probability that no crisis will take place in any of the months in 2008 and 2009. The ordered logit model does not pick up the mild currency crisis in October 2008.

\section{Brazil}

Table 1 shows crises forecasts for Brazil. Crisis probabilities differ from zero, but are fairly low. The probability of a mild crisis is equal to around 6 per cent at the end of 2008, the beginning of 2009. Brazil experienced a mild currency crisis in September-November 2008, which is not picked up by the EWS.

\section{Mexico}

Table 2 shows crises probability forecasts for Mexico. Crises probabilities are close to zero. Mexico experienced a very deep currency crisis in October 2008. This is not forecast by the ordered logit model. 
Table 1: Forecasts for Brazil for 2008-2009, for a mild, deep and very deep crisis

\begin{tabular}{|c|c|c|c|c|}
\hline period & P (no crisis) & $\begin{array}{r}\mathbf{P} \text { (mild } \\
\text { crisis) }\end{array}$ & $\begin{array}{r}\text { P (deep } \\
\text { crisis) }\end{array}$ & $\begin{array}{r}P \text { (v. deep } \\
\text { crisis) }\end{array}$ \\
\hline 2008M01 & $99.80 \%$ & $0.13 \%$ & $0.07 \%$ & $0.00 \%$ \\
\hline 2008M02 & $99.67 \%$ & $0.22 \%$ & $0.11 \%$ & $0.01 \%$ \\
\hline 2008M03 & $99.43 \%$ & $0.37 \%$ & $0.19 \%$ & $0.01 \%$ \\
\hline 2008M04 & $98.99 \%$ & $0.65 \%$ & $0.34 \%$ & $0.02 \%$ \\
\hline 2008M05 & $98.40 \%$ & $1.03 \%$ & $0.54 \%$ & $0.03 \%$ \\
\hline 2008M06 & $97.50 \%$ & $1.61 \%$ & $0.85 \%$ & $0.05 \%$ \\
\hline 2008M07 & $96.49 \%$ & $2.25 \%$ & $1.20 \%$ & $0.06 \%$ \\
\hline 2008M08 & $95.31 \%$ & $2.99 \%$ & $1.61 \%$ & $0.09 \%$ \\
\hline 2008M09 & $94.04 \%$ & $3.78 \%$ & $2.06 \%$ & $0.11 \%$ \\
\hline 2008M10 & $92.93 \%$ & $4.47 \%$ & $2.47 \%$ & $0.13 \%$ \\
\hline 2008M11 & $91.48 \%$ & $5.35 \%$ & $3.01 \%$ & $0.17 \%$ \\
\hline 2008M12 & $90.64 \%$ & $5.86 \%$ & $3.32 \%$ & $0.18 \%$ \\
\hline 2009M01 & $90.21 \%$ & $6.12 \%$ & $3.48 \%$ & $0.19 \%$ \\
\hline 2009M02 & $90.16 \%$ & $6.15 \%$ & $3.50 \%$ & $0.19 \%$ \\
\hline 2009M03 & $90.47 \%$ & $5.96 \%$ & $3.38 \%$ & $0.19 \%$ \\
\hline 2009M04 & $91.07 \%$ & $5.60 \%$ & $3.16 \%$ & $0.17 \%$ \\
\hline 2009M05 & $91.85 \%$ & $5.13 \%$ & $2.87 \%$ & $0.16 \%$ \\
\hline 2009M06 & $92.73 \%$ & $4.59 \%$ & $2.54 \%$ & $0.14 \%$ \\
\hline 2009M07 & $93.63 \%$ & $4.04 \%$ & $2.22 \%$ & $0.12 \%$ \\
\hline 2009M08 & $94.49 \%$ & $3.50 \%$ & $1.90 \%$ & $0.10 \%$ \\
\hline 2009M09 & $95.28 \%$ & $3.01 \%$ & $1.62 \%$ & $0.09 \%$ \\
\hline 2009M10 & $95.97 \%$ & $2.58 \%$ & $1.38 \%$ & $0.07 \%$ \\
\hline 2009M11 & $96.56 \%$ & $2.21 \%$ & $1.17 \%$ & $0.06 \%$ \\
\hline 2009M12 & $97.05 \%$ & $1.89 \%$ & $1.00 \%$ & $0.05 \%$ \\
\hline
\end{tabular}


Table 2: Forecasts for Mexico for 2008-2009, for a mild, deep and very deep crisis

$\begin{array}{lrrrr}\text { Period } & \text { P (no crisis) } & \begin{array}{r}\text { P (mild } \\ \text { crisis) }\end{array} & \begin{array}{r}\text { P (deep } \\ \text { crisis) }\end{array} & \begin{array}{r}\text { P (v. deep } \\ \text { crisis) }\end{array} \\ \text { 2008M01 } & 99.99 \% & 0.01 \% & 0.00 \% & 0.00 \% \\ \text { 2008M02 } & 99.99 \% & 0.01 \% & 0.00 \% & 0.00 \% \\ \text { 2008M03 } & 99.99 \% & 0.01 \% & 0.00 \% & 0.00 \% \\ \text { 2008M04 } & 99.99 \% & 0.01 \% & 0.00 \% & 0.00 \% \\ \text { 2008M05 } & 99.99 \% & 0.01 \% & 0.00 \% & 0.00 \% \\ \text { 2008M06 } & 99.99 \% & 0.01 \% & 0.00 \% & 0.00 \% \\ \text { 2008M07 } & 99.99 \% & 0.01 \% & 0.00 \% & 0.00 \% \\ \text { 2008M08 } & 99.99 \% & 0.01 \% & 0.00 \% & 0.00 \% \\ \text { 2008M09 } & 99.98 \% & 0.01 \% & 0.00 \% & 0.00 \% \\ \text { 2008M10 } & 99.98 \% & 0.02 \% & 0.00 \% & 0.00 \% \\ \text { 2008M11 } & 99.97 \% & 0.02 \% & 0.00 \% & 0.00 \% \\ \text { 2008M12 } & 99.96 \% & 0.03 \% & 0.01 \% & 0.00 \% \\ \text { 2009M01 } & 99.94 \% & 0.05 \% & 0.01 \% & 0.00 \% \\ \text { 2009M02 } & 99.92 \% & 0.07 \% & 0.01 \% & 0.00 \% \\ \text { 2009M03 } & 99.90 \% & 0.08 \% & 0.01 \% & 0.00 \% \\ \text { 2009M04 } & 99.88 \% & 0.11 \% & 0.02 \% & 0.00 \% \\ \text { 2009M05 } & 99.85 \% & 0.13 \% & 0.02 \% & 0.00 \% \\ \text { 2009M06 } & 99.83 \% & 0.15 \% & 0.02 \% & 0.00 \% \\ \text { 2009M07 } & 99.81 \% & 0.17 \% & 0.03 \% & 0.00 \% \\ 2009 \mathrm{M} 08 & 99.79 \% & 0.18 \% & 0.03 \% & 0.00 \% \\ 2009 \mathrm{M} 09 & 99.77 \% & 0.20 \% & 0.03 \% & 0.00 \% \\ 2009 \mathrm{M} 10 & 99.76 \% & 0.21 \% & 0.03 \% & 0.00 \% \\ 2009 \mathrm{M} 11 & 99.76 \% & 0.21 \% & 0.03 \% & 0.00 \% \\ 2009 \mathrm{M} 12 & 99.75 \% & 0.22 \% & 0.03 \% & 0.00 \%\end{array}$


In the late Fall of 2008 all three countries experienced a currency crisis (Argentina and Brazil: mild; Mexico: very deep). Based on information up to and including 2007, our ordered logit models did not pick up this crisis. Forecasts of the indicators that played an important role in earlier crises did not indicate a crisis.

It should be realized that the forecasts we present here are based solely on the information that is available in December 2007. For the years 2008 and 2009 the factors are extrapolated using time series models. So the global shock caused by the fall of Lehman Brothers in the USA in September 2008 is not taken into account. Using the realizations of the indicators we should be able to more precisely forecast crises. This could be done either by using the estimates from the factor models until 2007, or by re-estimating the factor models using the values of the indicators until and including the year 2009.

\section{Conclusion}

The fall of Lehman Brothers in September 2008 sent a shock all over the world; emerging markets were affected severely. Exchange rates depreciated by more than 40\% (Mexico, Brazil) and share prices decreased by more than 50\% (Argentina, Brazil). Despite relative solid fundamentals the currencies showed a sharp depreciation, particularly countries with high trade and financial flows with the USA and countries with fiscal, trade or financing balances deficits. International trade was also severely affected. Given the rich history of financial crises of the three Latin American countries that we studied, it is remarkable that in none of these countries the effect spread to the banking sector or affected debt servicing. In 2009 the exchange rates, stock prices and interest spreads reversed and returned to hoover between the pre-crisis and crisis levels.

This paper investigates why Latin America was relatively unharmed by the GFC. To that purpose we set up ordered logit models for Argentina, Brazil and Mexico, using 
dynamic factor models to reduce the dimension of the information set. We find that currency crises in Argentina and Brazil are driven by banking and commodities indicators, while international indicators matter most in Mexico. Furthermore, we see that in all three Latin American countries institutional indicators play a role. This result supports the fourth generation model in which institutional factors are important. It also confirms previous work in which political indicators play a significant role in crisis forecasting

With an improved institutional framework, a healthier financial system (better regulation, higher profitability margins, lower non-performing loans) and lower debt levels the countries have created a better environment than in the 1990s. This however does not mean that these countries "graduated from financial crises" - to borrow a term from Qian, Reinhart and Rogoff (2010). The LA-3 passed a serious test with the GFC, but its characteristics were very distinct from previous crises.

Future research will include: (i) using data with mixed frequencies (monthly, quarterly, annual) and incomplete series as in Aruoba, Diebold and Scotti (2009), which allows the inclusion of a wide range of indicators, particularly institutional indicators; (ii) adding banking crises and debt crises, in order to distinguish between currency crises which remain isolated as opposed to currency crises that are accompanied by other crises and generally have a stronger impact on the economy and a longer recovery period; and (iii) carrying out a real-time analysis. 


\section{A Data}

\begin{tabular}{|c|c|c|c|c|c|c|}
\hline & Indicator & Code & Definition and source & Transformation & Data freq & Countries \\
\hline \multicolumn{7}{|c|}{ Economic indicators: external sector } \\
\hline 1 & $\begin{array}{l}\text { Real Exchange Rate } \\
\text { (RER): deviation } \\
\text { from trend }\end{array}$ & RER_DEV & $\begin{array}{l}\text { RER }=e\left(P_{f} / P\right) \text {, with: } \\
\text { e = nominal exchange rate Local Currency Unit per US } \\
\text { dollar (IFS: AE.ZF) } \\
P=\text { domestic price level: Consumer Price Index (IFS: } \\
64 . . Z F) \\
P_{f}=\text { foreign price level: Consumer Price Inflation in } \\
\text { USA (IFS 111.64..ZF) }\end{array}$ & $\begin{array}{l}\text { deviation from } 5 \\
\text { year moving } \\
\text { average }\end{array}$ & Monthly & $A, B, M$ \\
\hline 2 & $\begin{array}{l}\text { Exchange rate } \\
\text { volatility }\end{array}$ & ERVOL & $\begin{array}{l}\text { Monthly volatility of the nominal exchange rate (IFS: } \\
A E . . Z F) \text { in the current month and the } 47 \text { months } \\
\text { preceding. }\end{array}$ & $\begin{array}{l}\text { Standard } \\
\text { deviation }\end{array}$ & Monthly & $A, B, M$ \\
\hline 3 & Export growth & D_EXP & Exports F.O.B.; in USD (IFS: 70.D..ZF) & $\begin{array}{l}12 \text { months } \\
\text { percentage } \\
\text { change }\end{array}$ & Monthly & $A, B, M$ \\
\hline 4 & Import growth & D_IMP & Imports F.O.B.; in USD (IFS: 71.VD..ZF) & $\begin{array}{l}12 \text { months } \\
\text { percentage } \\
\text { change }\end{array}$ & Monthly & $A, B, M$ \\
\hline 5 & Terms of Trade & TOT & $\begin{array}{l}\text { ToT = exports prices / imports prices } \\
\text { Two ways to define this: } \\
\text { (i) Export price index (= IFS-76) / import price index (= } \\
\text { IFS-76X) -Mex; } \\
\text { (ii) Unit value of exports: IFS-74D ; Unit value of } \\
\text { imports: IFS-75D - Arg \& Bra }\end{array}$ & None (ratio) & $\begin{array}{l}\text { Arg \& Bra (series } \\
\text { 74, 75): quarterly, } \\
\text { Mex (series 76): } \\
\text { monthly }\end{array}$ & $A, B, M$ \\
\hline 6 & $\begin{array}{l}\text { Ratio of Current } \\
\text { Account to GDP }\end{array}$ & CA_GDP & $\begin{array}{l}\text { Current account, in USD: IFS-78AL (78ALDZF...) = } \\
\text { balance on goods, services and income plus current } \\
\text { transfers. } \\
\text { GDP, in nominal USD: IFS 99, converted in USD by } \\
\text { average nominal exchange rate (IFS: ..RF.ZF... for Arg } \\
\text { \& Bra,..WF.ZF... for Mexico). }\end{array}$ & None (ratio) & Quarterly & $A, B, M$ \\
\hline 7 & $\begin{array}{l}\text { Net Portfolio } \\
\text { Investment / GDP }\end{array}$ & NETPI_GDP & $\begin{array}{l}\text { Portfolio assets (IFS: 78BFDZF...) - portfolio liabilities } \\
\text { (IFS: 78BGDZF...). Both in USD. GDP in USD: see } \\
\text { CA_GDP }\end{array}$ & None (ratio) & Quarterly & $A, B, M$ \\
\hline 8 & Ratio FDI to GDP & NETFDI_GDP & $\begin{array}{l}\text { FDI outflow = IFS series 78BDDZF... and FDI inflow = } \\
\text { IFS series 78BEDZF... (both in USD). } \\
\text { Arg and Bra: net FDI; Mex: FDI inflow } \\
\text { GDP in USD: see CA_GDP }\end{array}$ & None (ratio) & Quarterly & $A, B, M$ \\
\hline 9 & $\begin{array}{l}\text { Ratio of Financial } \\
\text { Account to GDP }\end{array}$ & FA_GDP & $\begin{array}{l}\text { Financial account = balance of all accounts: from trade } \\
\text { to FDI and portfolio investments. } \\
\text { Financial Account = IFS: 78BJDZF... } \\
\text { GDP in USD: see CA_GDP. }\end{array}$ & None (ratio) & Quarterly & $B, M$ \\
\hline 10 & Trade openness & D_TRD_OPEN & $\begin{array}{l}\text { Trade openness = sum of absolute value of exports } \\
\text { and imports, divided by nominal GDP in USD. } \\
\text { IFS: 78AADZF... +78ADDZF... (= exports of goods and } \\
\text { services) and 78ABDZF... +78AEDZF... (= imports of } \\
\text { goods and services) } \\
\text { GDP in USD: see CA_GDP }\end{array}$ & $\begin{array}{l}12 \text { months } \\
\text { percentage } \\
\text { change }\end{array}$ & Quarterly & $A, B, M$ \\
\hline 11 & $\begin{array}{l}\text { Growth of forex } \\
\text { reserves }\end{array}$ & D_RES & $\begin{array}{l}\text { Foreign exchange reserves, excluding gold; in USD } \\
\text { (IFS: 1.LD..DZF) }\end{array}$ & $\begin{array}{l}12 \text { months } \\
\text { percentage } \\
\text { change }\end{array}$ & Monthly & $A, B, M$ \\
\hline 12 & $\begin{array}{l}\text { Ratio of } \mathrm{M} 2 \text { to forex } \\
\text { reserves }\end{array}$ & M2RES & $\begin{array}{l}\text { M2: IFS series 59MB.ZF... (Arg > 2000; Bra \& Mex), } \\
\text { Central Bank Rep.Argentina (<2000, Arg). } \\
\text { Converted into USD with end-of-period nominal } \\
\text { exchange rate: IFS series ..AE.ZF...; Foreign Exchange } \\
\text { Reserves: IFS series .1L.DZF... }\end{array}$ & None (ratio) & Monthly & $A, B, M$ \\
\hline 13 & Import cover & D_IMPCOV & $\begin{array}{l}\text { Forex Reserves excl.gold from IFS, in USD (.1L.DZF...) } \\
\text { and imports F.O.B. from IFS, in USD (IFS: 71.VD..ZF) }\end{array}$ & $\begin{array}{l}12 \text { months } \\
\text { percentage } \\
\text { change }\end{array}$ & Monthly & $A, B, M$ \\
\hline
\end{tabular}


Economic indicators: domestic real and public sector
1 real GDP growth

1 real GDP growth D_RGDP GDP in nominal LCU. IFS: 99B..ZF... (Arg > 1995; Bra

Quarterly

A, B, M

Consumer Price index (IFS: 64..ZF...)

percentage

2 GDP per capita D_RGDPCAP

change

GDP: see D_RGDP:

Total population: IFS-99Z.

12 months Annual A, B, M

3 Unemployment D UNEMPL

Unemployment as \% of (\# unemployed +\#

percentage

change

employed). IFS: 67R..ZF..

12 months Annual $<2001$, B

percentage quarterly $>$

change

2001

4 Government

GOVCONS_GDP

Gov.Cons. (in LCU): IFS 91F..ZF...

None (ratio)

Quarterly

B, M

expenditure to

GDP (in LCU): IFS 99B

None (ratio)

Arg < 1993:

A, B, M

Household

HHCONS_GDP Household cons: IFS series 96F..ZF...

GDP (in LCU): IFS 99B

expenditure (incl.

annual, $>1993$

quarterly;

Bra \& Mex

quarterly

Gov't revenues: integrate two incomplete series

(IFS: $11 \ldots$ BA... and $a 1 \ldots$......).

12 months

Quarterly

$B, M$

government

GDP (in LCU): IFS 99B

percentage

change

7 Ratio of

D_GOVEXP

Gov't expenses: integrate two incomplete series

12 months

(IFS: $\mathrm{c} 2 \ldots \mathrm{BA} \ldots$ and $\mathrm{a} 2 \ldots \mathrm{CG} \ldots$...

percentag

expenses to GDP

GDP (in LCU): IFS 99B

None (ratio) Quarterly

B, M

8 fiscal balance to GOVBAL_GDP

Budget $=$ difference between revenues (IFS:

B, M

c1...BA... and a1...CG...) and expenses (IFS: c2...BA...

and a2...CG...)

GDP (in LCU): IFS 99B

9 Change in INVCHG_GDP Change in inventories (in

GDP (in LCU): 99B.RWF..

None (ratio)

Quarterly

M

inventories to GDP

Consumer Price Inflation (IFS: 64..ZF)

12 months

Monthly

A, B, M

10 Inflation (CPI) INFLAT

Industrial production index: Bra \& Mex: IFS-66.

percentage

change

12 months

percentage

industrial

D_INDPROD

Arg: Datastream (code AGIPTOT G)

change

12 Domestic Savings GDSAV_GDP

Ratio of savings to GDP: WDI-code: NY.GDS.TOTL.ZS None (ratio)

Monthly

A, B, M

13 Gross capital GFCAP_GDP

Arg \& Mex: 93E.CZF... and 99B.RWF... (quarterly)

Bra: WDI code: NE.GDI.TOTL.KD.ZG (annual)

12 months

percentage

Annual

A, B, M

formation

6 month time deposit rate deflated by CPI:

$\operatorname{Arg} \&$ Mex

A, B, M

14 Domestic real REALINT interest rate

$\left(1+R_{\text {nominal }}\right) /(1+$ Inflation $)-1$, with:

See formula

6 months time deposit rate (IFS: 60L..ZF)

15 M2 growth (real D_M2

CPI (IFS: 64..ZF)

LCU)

M2: see M2RES

12 months

A, B, M

16 M2 money

M2MULT

Ratio of $\mathrm{M} 2$ to monetary base.

ercentage

change

ratio

Monthly

A, B, M

Base money: IFS: 19MA.ZF.. 
Financial market indicators

1 Sovereign Bond INTSPREAD Interest Rate

Spreads, basis

points over US

Treasuries

2 J.P. Morgan EMBI_RET

Emerging Markets

Bond Index

$(\mathrm{EMBI}+)$ : monthly

return

3 Return on the STOCKRET

major stock index
GEM: difference between local government interest None (spread) rate on bonds in USD and US government on bonds

in USD.

GEM: index that measures the value of the bonds. Monthly return Monthly B

Major stock index from each country (IPC for

Mexico, Merval for Argentina and BOVESPA for

Monthly return Monthly A, B, M

Brazil). In own currency. Source: Economatica.

5 Debt reduction / REDU_TDEBT

total debt

Total debt: (WDI code) DT.DOD.DECT.CD

reserves to tota

D_RES_DEBT

external debt

9 Ratio of debt

DSERV_EXP

service to exports

10 Ratio of debt DSERV_RES service to reserves

Reserves (IFS code): .1L.DZF...
WDI code for total -external- debt (in USD):

DT.DOD.DECT.CD

GDP (in USD): see CA_GDP

Short term debt: (WDI code) DT.DOD.DSTC.CD

Total debt: (WDI code) DT.DOD.DECT.CD

IMF credit: (WDI code) DT.DOD.DIMF.CD

GDP (in USD): see CA GDP

WDI code for interest arrears (USD):

DT.IXA.DPPG.CD

WDI code for principal arrears (USD):

DT.AXA.DPPG.CD

WDI code for total external debt (USD):

DT.DOD.DECT.CD

Debt reduction: (WDI code) DT.DFR.DPPG.CD

LT Private and Non Guaranteed debt: (WDI code) DT.DOD.PRVS.CD

Total debt: (WDI code) DT.DOD.DECT.CD

LT Public and Publicly Guaranteed debt: (WDI code) DT.DOD.PUBS.CD

Total debt: (WDI code) DT.DOD.DECT.CD

Total debt: (WDI code) DT.DOD.DECT.CD

Reserves (IFS code): .1L.DZF..

WDI code for debt service (current USD)

DT.TDS.DECT.CD IFS code for exports (millions of

current USD): 70..DZF..

Debt service (WDI code): DT.TDS.DECT.CD

$\begin{array}{lll}\text { None (ratio) } & \text { Annual } & \text { A, B , M } \\ \text { None (ratio) } & \text { Annual } & \text { A, B , M } \\ \text { None (ratio) } & \text { Annual } & \text { A, B, M } \\ \text { None (ratio) } & \text { Annual } & \text { A, B , M }\end{array}$

None (ratio)

Annual

$A, B, M$

12 months percentage change.

Annual $\quad A, B, M$

Annual $\quad A, B, M$

percentage

change.

12 months Annual A, B , M

percentage

change

None (ratio)

Annual $\quad A, B, M$

None (ratio) Annual A, B, M

Domestic credit provided by banking sector (\% of None (ratio) Annual A, M GDP) (WDI code $=$ FS.AST.DOMS.GD.ZS)

minus

Domestic credit to private sector (\% of GDP)

(WDI code $=$ FS.AST.PRVT.GD.ZS)

Domestic credit provided by banking sector (\% of None (ratio) Annual A, B, M GDP). WDI code = FS.AST .DOMS.GD.ZS
2 Ratio of lending to GDP
DCREDBANK 
3 Liquid liabilities (\% D LIQLIAB of GDP)

4 Central bank CBASSET assets (\% of GDP)

5 Deposit money D_DMBANKAS bank assets (\% of GDP)

6 Private credit by all D_PCRED_GDP financial institutions (\% of GDP)

7 Private credit by D_PCRED_DMB deposit money banks (\% of GDP)

8 Private credit by D_PCRED_OTH other financial institutions (\% of GDP)

9 Financial system D_FSDEPOS deposits (\% of GDP)

Ratio Bank credit D_BCRED_BDEP to bank deposits

11 Net interest NETINTMG margin

12 Bank BANKCONC concentration

13 Bank ROE BANKROE

14 Bank Z-Score BANKZ

15 Deposit money banks and other banking instit: assets

16 Deposit money banks and other banking institutions: liabilities

17 CB: foreign assets - D_CB_FA_FL foreign liabilities

18 CB: claims deposits from central government
Code: II usd. Source: Financial Structure, from World Bank (FS/WB) and Beck et al. 2000, 2009

12 months percentage change

Claims on domestic real nonfinancial sector by the 12 months Central Bank as a share of GDP. FS/WB code: cbagdp percentage

change

Claims on domestic real nonfinancial sector by deposit money banks as a share of GDP. FS/WB code: dbagdp

12 months percentage change

Private credit by deposit money banks and other financial institutions to GDP.

FS/WB code: pcrdbofgdp

12 months percentage change

Private credit by deposit money banks to GDP. FS/WB code: pcrdbgdp

12 months percentage change

Private credit by other financial institutions to GDP. 12 months Difference between private credit by all percentage fin.institutions and private credit by deposit money change banks. FS/WB

code: pcrdbofgdp - pcrdbgdp

Demand, time and saving deposits in deposit money 12 months banks and other financial institutions as a share of percentage GDP change

FS/WB code: fdgdp

Private credit by deposit money banks as a share of 12 months banks.

change

FS/WB code: bcbd

Accounting value of bank's net interest revenue as a None share of its interest-bearing (total earning) assets.

FS/WB code: netintmargin

Assets of three largest banks as a share of assets of None all commercial banks.

FS/WB code: concentration

Average Return on Equity (Net Income/Total None

Equity). FS/WB code: roe

$Z=1.2 A+1.4 B+3.3 C+0.6 D+1.0 E$ with: None

Annual

A, B, M

Annual B

Annual $\quad A, B, M$

Annual A

Annual A, B, M

Annual B, M

$A=$ Working Capital $/$ Total Assets

$B=$ Retained Earnings/Total Assets

$\mathrm{C}=\mathrm{EBIT} /$ Total Assets

$\mathrm{D}=$ Market Value of Equity/Total Liab

$\mathrm{E}=$ Sales/Total Assets

12 months

percentage

Monthly A

Deposit money banks Assets (IFS: 7A.DZF...)

change

Sum of:

12 months

percentage

Annual

A, B, M

Annual

A, B, M

Annual

A, B, M

Annual

A, B, M

Deposit money banks Liabilities (IFS: 7B.DZF ..)

change

Difference between:

Foreign assets (IFS: 11...ZF...)

Foreign liabilities (16C..ZF...)

12 months

percentage

change

Difference between:

Claims on central government (IFS: 12A..ZF...)

12 months

percentage

Annual $\quad A, B, M$

Annual B

Central government deposits (IFS 16D..ZF...)
Monthly A

Monthly A 


\begin{tabular}{|c|c|c|c|c|c|c|}
\hline 19 & $\begin{array}{l}\text { CB: claims on } \\
\text { deposit money } \\
\text { banks and other } \\
\text { banking inst. }\end{array}$ & D_CB_BANKS & $\begin{array}{l}\text { Sum of: } \\
\text { Claims on Deposit Money Banks (IFS: 12E..ZF...) } \\
\text { Claims on Other banking institutions (IFS: 12F..ZF...) }\end{array}$ & $\begin{array}{l}12 \text { months } \\
\text { percentage } \\
\text { change }\end{array}$ & Monthly & A \\
\hline 20 & $\begin{array}{l}\text { Bank sector: } \\
\text { reserves }\end{array}$ & D_BANKRES & $\begin{array}{l}\text { Sum of: } \\
\text { Reserves from DMB (IFS: } 20 \ldots Z \text { FF...) } \\
\text { Reserves from other banking institutions (IFS: } \\
40 \ldots . . Z F \text {..) }\end{array}$ & $\begin{array}{l}12 \text { months } \\
\text { percentage } \\
\text { change }\end{array}$ & Monthly & A \\
\hline 21 & $\begin{array}{l}\text { Bank sector: } \\
\text { Foreign assets - } \\
\text { foreign liabilities }\end{array}$ & D_BANK_FA_FL & 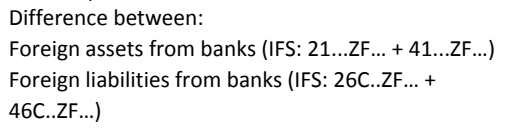 & $\begin{array}{l}12 \text { months } \\
\text { percentage } \\
\text { change }\end{array}$ & Monthly & A \\
\hline 22 & $\begin{array}{l}\text { Bank sector: claims } \\
\text { on PPG }\end{array}$ & D_BANK_PPG & $\begin{array}{l}\text { Claims on PPG: } \\
\text { Claims on central govt (IFS: 22A..ZF... + 42A..ZF... ) } \\
\text { Claims on state and local government (IFS: 22B..ZF... } \\
+42 B . . Z F . . \text { ) } \\
\text { Claims on official entities (IFS: 22BX.ZF... } \\
\text { 42BX.ZF...) }\end{array}$ & $\begin{array}{l}12 \text { months } \\
\text { percentage } \\
\text { change }\end{array}$ & Monthly & A \\
\hline 23 & $\begin{array}{l}\text { Banks: claims on } \\
\text { private sector }\end{array}$ & D_BANK_PRIV & $\begin{array}{l}\text { Claims from DMB and other banking instit. on } \\
\text { private sector (IFS: 22D..ZF... and 42D..ZF...) }\end{array}$ & $\begin{array}{l}12 \text { months } \\
\text { percentage } \\
\text { change }\end{array}$ & Monthly & A \\
\hline 24 & $\begin{array}{l}\text { Banks: demand } \\
\text { deposits }\end{array}$ & $\begin{array}{l}\text { D_BANK_ } \\
\text { DEM_DEPOS }\end{array}$ & Demand deposits in DMB (IFS: $24 \ldots . . Z F . .)$. & $\begin{array}{l}12 \text { months } \\
\text { percentage } \\
\text { change }\end{array}$ & Monthly & A \\
\hline 25 & $\begin{array}{l}\text { Banks: time, } \\
\text { savings and foreign } \\
\text { currency deposits }\end{array}$ & $\begin{array}{l}\text { D_BANK_TSFC_DE } \\
\text { POS }\end{array}$ & $\begin{array}{l}\text { Time, savings and foreign currency deposits (IFS: } \\
25 \ldots Z F \ldots+45 \ldots Z F \ldots \text { ) }\end{array}$ & $\begin{array}{l}12 \text { months } \\
\text { percentage } \\
\text { change }\end{array}$ & Monthly & A \\
\hline \multicolumn{7}{|c|}{ Institutional indicators: indices } \\
\hline 1 & $\begin{array}{l}\text { Herfindahl Index } \\
\text { Government }\end{array}$ & HERFGOV & $\begin{array}{l}\text { DPI (World Bank / Beck et al. 2001): herfgov. } \\
\text { Represents a measure of government coalition } \\
\text { concentration, by squaring the percentage of parties } \\
\text { in the government coalition. The presence of a } \\
\text { majority party in the government coalition increases } \\
\text { the index. Having many (small) parties in the } \\
\text { government reduces it. }\end{array}$ & None. & Annual & $A, B, M$ \\
\hline 2 & $\begin{array}{l}\text { Herfindahl Index } \\
\text { Opposition }\end{array}$ & HERFOPP & $\begin{array}{l}\text { DPI: herfopp. Idem herfgov, but now for } \\
\text { government opposition. }\end{array}$ & None. & Annual & $B, M$ \\
\hline 3 & Political stability & D_GOVSTAB & $\begin{array}{l}\text { On a scale from } 0 \text { to } 12 \text {, with } 12 \text { the highest level of } \\
\text { stability and } 0 \text { the highest level of instability. Source: } \\
\text { ICRG }\end{array}$ & $\begin{array}{l}12 \text { months } \\
\text { percentage } \\
\text { change. }\end{array}$ & Annual & $A, B, M$ \\
\hline 4 & $\begin{array}{l}\text { Socioeconomic } \\
\text { Conditions }\end{array}$ & D_SOCIOECO & $\begin{array}{l}\text { On a scale from } 0 \text { to } 12 \text {, with } 12 \text { the highest level of } \\
\text { socioeconomic conditions and } 0 \text { the lowest level. } \\
\text { Source: ICRG }\end{array}$ & $\begin{array}{l}12 \text { months } \\
\text { percentage } \\
\text { change }\end{array}$ & Annual & $A, B, M$ \\
\hline 5 & Investment Profile & D_INVPROF & $\begin{array}{l}\text { On a scale from } 0 \text { to } 12 \text {, with } 12 \text { the best investment } \\
\text { profile (= low risk) and } 0 \text { the worst profile. Source: } \\
\text { ICRG }\end{array}$ & $\begin{array}{l}12 \text { months } \\
\text { percentage } \\
\text { change }\end{array}$ & Annual & $A, B, M$ \\
\hline 6 & Internal Conflict & D_INTCONFL & $\begin{array}{l}\text { On a scale from } 0 \text { to } 12 \text {, with } 12 \text { the lowest level of } \\
\text { internal conflict (low risk) and } 0 \text { the highest level } \\
\text { (high risk). Source: ICRG }\end{array}$ & $\begin{array}{l}12 \text { months } \\
\text { percentage } \\
\text { change }\end{array}$ & Annual & $A, B, M$ \\
\hline 7 & $\begin{array}{l}\text { Democratic } \\
\text { Accountability }\end{array}$ & D_DEMACC & $\begin{array}{l}\text { On a scale from } 0 \text { to } 6 \text {, with } 6 \text { the highest level of } \\
\text { dem.accountability and } 0 \text { the lowest level. Source: } \\
\text { ICRG }\end{array}$ & $\begin{array}{l}12 \text { months } \\
\text { percentage } \\
\text { change }\end{array}$ & Annual & $A, B, M$ \\
\hline
\end{tabular}




\begin{tabular}{|c|c|c|c|c|c|c|}
\hline 8 & Corruption & D_CORRUPT & ICRG. Scale 6 (low corruption) to 0 (high corruption). & $\begin{array}{l}12 \text { months } \\
\text { percentage } \\
\text { change }\end{array}$ & Annual & $A, B, M$ \\
\hline 9 & Law and Order & D_LAWORD & $\begin{array}{l}\text { ICRG. Scale } 6 \text { (high law and order) to } 0 \text { (low law and } \\
\text { order). }\end{array}$ & $\begin{array}{l}12 \text { months } \\
\text { percentage } \\
\text { change }\end{array}$ & Annual & $A, B, M$ \\
\hline 10 & $\begin{array}{l}\text { Bureaucracy } \\
\text { Quality }\end{array}$ & D_BURQUAL & $\begin{array}{l}\text { ICRG. Scale } 4 \text { (high bureaucratic quality) to } 0 \text { (low } \\
\text { bureaucratic quality). }\end{array}$ & $\begin{array}{l}12 \text { months } \\
\text { percentage } \\
\text { change }\end{array}$ & Annual & $A, B, M$ \\
\hline \multicolumn{7}{|c|}{ Institutional indicators: dummies (not included in factor model) } \\
\hline 1 & $\begin{array}{l}\text { Party orien-tation } \\
\text { with resp. to econ. } \\
\text { policy }\end{array}$ & GOVT_RLC & $\begin{array}{l}\text { Dummy indicates orientation of the executive } \\
\text { power. Right (1); Left (3); Center (2); No information } \\
\text { (0). DPI code: execrlc }\end{array}$ & None & Annual & $A, B, M$ \\
\hline 2 & $\begin{array}{l}\text { Absolute majority } \\
\text { in the houses }\end{array}$ & GOVT_MAJ & $\begin{array}{l}\text { Dummy indicates if executive has absolute majority } \\
\text { in the houses. } 1=\text { yes, } 0=\text { no. DPI code: allhouse }\end{array}$ & None & Annual & $A, B, M$ \\
\hline 3 & $\begin{array}{l}\text { Degree of } \\
\text { polarization }\end{array}$ & POLARIZ & $\begin{array}{l}\text { Polarization is the maximum difference between the } \\
\text { chief executive's party's value (EXECRLC) and the } \\
\text { values of the three largest government parties and } \\
\text { the largest opposition party. } 0 \text { = no polarization. DPI } \\
\text { code: polariz }\end{array}$ & None & Annual & $A, B, M$ \\
\hline 4 & $\begin{array}{l}\text { date of elections } \\
\text { for executive } \\
\text { power }\end{array}$ & ELECEXE & $\begin{array}{l}\text { Dummy variable with value } 1 \text { in the month of } \\
\text { elections for executive power and } 0 \text { otherwise (DPI: } \\
\text { dateexec, exelec) }\end{array}$ & $\begin{array}{l}\text { The calender year } \\
\text { of the elections is } \\
\text { assigned } 1 .\end{array}$ & Monthly & $A, B, M$ \\
\hline 5 & $\begin{array}{l}\text { Contagion of crises } \\
\text { in the region }\end{array}$ & CONTAG & $\begin{array}{l}\text { Based on EMPI calculations: dummy }=1 \text { if there is a } \\
\text { financial crisis in one of the other LA } 3 \text { countries }\end{array}$ & None & Monthly & $A, B, M$ \\
\hline \multicolumn{7}{|c|}{ Global economy indicators } \\
\hline 1 & $\begin{array}{l}\text { US long term } \\
\text { interest rate }\end{array}$ & D_USYIELD & $\begin{array}{l}\text { Yield on the } 10 \text { year US government bond (IFS: } \\
\text { 111.61.ZF) }\end{array}$ & $\begin{array}{l}12 \text { months } \\
\text { percentage } \\
\text { change }\end{array}$ & Monthly & USA \\
\hline 2 & $\begin{array}{l}\text { US short term } \\
\text { interest rate }\end{array}$ & TBILL & IFS: $11160 C . . Z F . .$. & None & Monthly & USA \\
\hline 3 & $\begin{array}{l}\text { US real GDP } \\
\text { growth }\end{array}$ & D_GDPUSA & IFS series: 11199B.CZF... and 11164..ZF... & $\begin{array}{l}12 \text { months } \\
\text { percentage } \\
\text { change }\end{array}$ & Quarterly & USA \\
\hline 4 & $\begin{array}{l}\text { GDP VOLUME \% } \\
\text { CHANGE }\end{array}$ & D_GDPWORLD & $\begin{array}{l}\text { Change (year-on-year) of the volume of the GDP } \\
\text { growth. IFS series 00199BPXZF... }\end{array}$ & None & Annual & world \\
\hline \multicolumn{7}{|c|}{ Commodity indicators } \\
\hline 1 & $\begin{array}{l}\text { Agriculture, value } \\
\text { added (\% of GDP) }\end{array}$ & D_VA_AGRI & WDI code: NV.AGR.TOTL.ZS & $\begin{array}{l}12 \text { months } \\
\text { percentage } \\
\text { change }\end{array}$ & Annual & $A, B, M$ \\
\hline 2 & Oil prices & D_PR_PETROL & World oil price (IFS: 00176AADZF...) & $\begin{array}{l}12 \text { months } \\
\text { percentage } \\
\text { change }\end{array}$ & Monthly & world \\
\hline 3 & $\begin{array}{l}\text { Agricultural } \\
\text { commodities price } \\
\text { index }\end{array}$ & D_PR_AGRI & $\begin{array}{l}\text { Global agricultural raw materials price index (IFS: } \\
\text { 00176BXDZF) }\end{array}$ & $\begin{array}{l}12 \text { months } \\
\text { percentage } \\
\text { change }\end{array}$ & Monthly & world \\
\hline 4 & $\begin{array}{l}\text { Metals } \\
\text { commodities price } \\
\text { index }\end{array}$ & D_PR_METAL & Global metals price index (IFS: 00176AYDZF) & $\begin{array}{l}12 \text { months } \\
\text { percentage } \\
\text { change }\end{array}$ & Monthly & world \\
\hline
\end{tabular}


5 Agricultural raw D_AGRI_EXP materials exports:
Agricult

Elaborated from the following series:

Agricultural raw material exports, as \% of

merchandise exports. Source: WDI, code:

TX.VAL.AGRI.ZS.UN

Goods exports (BoP, current US\$; Source: WDI,

code: BX.GSR.MRCH.CD)

GDP (current US\$; Source: WDI, code:

NY.GDP.MKTP.CD)

6 Food materials D_FOOD_EXP exports:

7 Fuel exports: D_FUEL_EXP

code: TX.VAL.FOOD.ZS.UN

Idem, but fuel exports. Source: WDI, code:

TX.VAL.FUEL.ZS.UN

Ores and metals D_METAL_EXP exports:

Idem but ores and metals exports. Source: WDI,

Idem code: TX.VAL.MMTL.ZS.UN

Agricultural raw material imports, expressed as \% of Idem Agricultural raw D_AGRI_IMP
materials imports: GDP.

Elaborated from the following series:

Agricultural raw material imports, as $\%$ of

merchandise imports. Source: WDI, code:

TM.VAL.AGRI.ZS.UN

Goods imports (BoP, current US\$; Source: WDI,

code: BM.GSR.MRCH.CD)

GDP (current US\$; Source: WDI, code:

NY.GDP.MKTP.CDI

10 Food materials D_FOOD IMP

Idem, but food materials imports. Source: WDI,

code: TM.VAL.FOOD.ZS.UN

imports:

11 Fuel imports:

D_FUEL_IMP

Idem, but fuel imports. Source: WDI, code:

TM.VAL.FUEL.ZS.UN

12 Ores and metals

D_METAL_IMP imports:
TM.VAL.FUEL.ZS.UN

code: TM.VAL.MMTL.ZS.UN
Idem

Annual A, B, M

percentage

change

$\begin{array}{cr}\text { Annual } & \text { A, B, M } \\ \text { Annual } & \text { A, B, M } \\ \text { Annual } & \text { A, B, M } \\ \text { Annual } & \text { A, B, M }\end{array}$

Annual $\quad A, B, M$

Annual A, B, M

Annual A, B, M 


\section{B Correlations of factors with indicators}

ARGENTINA

For each of the 11 factors: ten variables with highest correlation with the factor

Factor 1

\begin{tabular}{|l|r|l|}
\hline D_BANK_PRIV & 0.8789 & bank \\
\hline D_BANK_TSFC_DEPOS & 0.7811 & bank \\
\hline BANKROE & 0.7953 & bank \\
\hline D_DMBANKAS & -0.8492 & bank \\
\hline NETINTMG & -0.7781 & bank \\
\hline DCREDBANK & -0.8505 & bank \\
\hline D_VA_AGRI & -0.8549 & commodity \\
\hline D_AGRI_EXP & -0.7831 & commodity \\
\hline D_FOOD_EXP & -0.8734 & commodity \\
\hline D_METAL_EXP & -0.8064 & commodity \\
\hline
\end{tabular}

Factor 4

\begin{tabular}{|l|r|l|}
\hline M2MULT & 0.5068 & eco dom \\
\hline D_FSDEPOS & -0.5708 & bank \\
\hline NETINTMG & -0.4619 & bank \\
\hline D_LIQLIAB & -0.5828 & bank \\
\hline D_PCRED_DMB & -0.4497 & bank \\
\hline D_LTPNG_DEBT & -0.5801 & debt \\
\hline DSERV_EXP & 0.5373 & debt \\
\hline DSERV_RES & 0.7348 & debt \\
\hline D_BURQUAL & -0.5885 & institutional \\
\hline D_GOVSTAB & 0.5199 & institutional \\
\hline
\end{tabular}

Factor 7

\begin{tabular}{|l|r|l|}
\hline D_M2 & -0.5498 & Eco Dom \\
\hline INFLAT & 0.4025 & Eco Dom \\
\hline D_GDPUSA & -0.4027 & global \\
\hline D_BANKRES & -0.4359 & bank \\
\hline D_BCRED_BDEP & 0.3246 & bank \\
\hline D_FSDEPOS & -0.3851 & bank \\
\hline D_LIQLIAB & -0.4289 & bank \\
\hline D_PCRED_DMB & -0.3303 & bank \\
\hline STD_DEBT & 0.3857 & debt \\
\hline D_INTCONFL & -0.3555 & institutional \\
\hline
\end{tabular}

\section{Factor 10}

Factor 10
\begin{tabular}{|l|r|l|}
\hline D_EXP & 0.3209 & Eco Ext \\
\hline D_IMPCOV & -0.2908 & Eco Ext \\
\hline D_USYIELD & 0.2451 & global \\
\hline D_BANKLIAB & 0.3482 & bank \\
\hline D_BANK_PPG & -0.3082 & bank \\
\hline D_LIQLIAB & -0.2477 & bank \\
\hline D_LTPPG_DEBT & 0.4191 & debt \\
\hline REDU_TDEBT & 0.3116 & debt \\
\hline STD_DEBT & -0.2971 & debt \\
\hline D_INVPROF & 0.2992 & institutional \\
\hline
\end{tabular}

Factor 2

\begin{tabular}{|l|r|l|}
\hline REALINT & 0.6532 & Eco Dom \\
\hline D_INDPROD & -0.7123 & Eco Dom \\
\hline M2MULT & 0.7574 & Eco Dom \\
\hline D_RGDP & -0.6483 & Eco Dom \\
\hline GDSAV_GDP & -0.7204 & Eco Dom \\
\hline D_IMP & -0.6938 & Eco Ext \\
\hline ERVOL & -0.7968 & Eco Ext \\
\hline BANKCONC & -0.6978 & bank \\
\hline DCREDPUB & -0.6780 & bank \\
\hline ARR_TDEBT & -0.8781 & debt \\
\hline
\end{tabular}

Factor 5

\begin{tabular}{|l|r|l|}
\hline D_GDPUSA & 0.3864 & Global \\
\hline D_BANKASSET & 0.5400 & bank \\
\hline D_BANKLIAB & 0.4369 & bank \\
\hline D_CB_CGVT & -0.5357 & bank \\
\hline D_AGRI_IMP & 0.3804 & commodity \\
\hline D_CORRUPT & -0.4420 & institutional \\
\hline D_INTCONFL & -0.6104 & institutional \\
\hline D_LAWORD & -0.4351 & institutional \\
\hline D_SOCIOECO & -0.4210 & institutional \\
\hline D_BURQUAL & -0.3749 & institutional \\
\hline
\end{tabular}

Factor 8

\begin{tabular}{|l|r|l|}
\hline NETFDI_GDP & 0.4135 & Eco Ext \\
\hline D_GDPUSA & 0.2891 & global \\
\hline D_USYIELD & 0.3807 & global \\
\hline D_BANKASSET & -0.2959 & bank \\
\hline D_CB_CGVT & -0.4553 & bank \\
\hline D_BANKRES & -0.3297 & bank \\
\hline D_PR_AGRI & 0.3715 & commodity \\
\hline D_PR_PETROL & 0.5764 & commodity \\
\hline DSERV_EXP & 0.3828 & debt \\
\hline HERFGOV & -0.4756 & institutional \\
\hline
\end{tabular}

Factor 11

\begin{tabular}{|l|r|l|}
\hline M2RES & 0.3006 & Eco Ext \\
\hline TOT & -0.3490 & Eco Ext \\
\hline D_GDPUSA & 0.2690 & global \\
\hline D_BANK_FA_FL & 0.2962 & bank \\
\hline D_BANK_PPG & -0.3225 & bank \\
\hline D_FUEL_EXP & -0.3080 & commodity \\
\hline D_PR_AGRI & -0.2962 & commodity \\
\hline D_LTPNG_DEBT & 0.2689 & debt \\
\hline D_LTPPG_DEBT & -0.3998 & debt \\
\hline D_INVPROF & 0.3288 & institutional \\
\hline
\end{tabular}

Factor 3

\begin{tabular}{|l|r|l|}
\hline GFCAP_GDP & -0.6160 & Eco Dom \\
\hline HHCONS_GDP & 0.6044 & Eco Dom \\
\hline INFLAT & 0.5475 & Eco Dom \\
\hline TOT & -0.5990 & Eco Ext \\
\hline D_TBILL & -0.7488 & global \\
\hline D_GDPWORLD & -0.6921 & global \\
\hline D_BCRED_BDEP & -0.6112 & bank \\
\hline D_CB_BANKS & 0.5518 & bank \\
\hline D_PR_METAL & -0.6684 & commodity \\
\hline D_CORRUPT & 0.5951 & institutional \\
\hline
\end{tabular}

Factor 6

\begin{tabular}{|l|r|l|}
\hline UNEMPL & 0.4022 & Eco Dom \\
\hline D_IMP & 0.2938 & Eco Ext \\
\hline M2RES & 0.5223 & Eco Ext \\
\hline D_IMPCOV & -0.5443 & Eco Ext \\
\hline D_BANK_PPG & 0.5365 & bank \\
\hline BANKROE & -0.3773 & bank \\
\hline D_BCRED_BDEP & -0.4395 & bank \\
\hline D_PCRED_GDP & -0.3933 & bank \\
\hline D_LTPPG_DEBT & -0.3667 & debt \\
\hline D_SOCIOECO & -0.5023 & institutional \\
\hline
\end{tabular}

Factor 9

\begin{tabular}{|l|r|l|}
\hline GOVCONS_GDP & 0.2874 & Eco Dom \\
\hline D_RES & -0.2846 & Eco Ext \\
\hline D_BANKLIAB & -0.3034 & bank \\
\hline D_PCRED_DMB & 0.2717 & bank \\
\hline D_FOOD_IMP & -0.5438 & commodity \\
\hline D_FUEL_IMP & -0.3567 & commodity \\
\hline D_METAL_IMP & -0.3711 & commodity \\
\hline D_LTPNG_DEBT & 0.3432 & debt \\
\hline D_RES_DEBT & 0.4292 & debt \\
\hline REDU_TDEBT & -0.3841 & debt \\
\hline
\end{tabular}

\begin{tabular}{lll}
\hline REDU_TDEBT & -0.3841 & debt
\end{tabular} 
BRAZIL

For each of the 9 factors: ten variables with highest correlation with the factor

Factor 1

\begin{tabular}{|l|r|l|}
\hline PCRED_DMB & 0.7039 & Bank \\
\hline PCRED_OTH & 0.6966 & Bank \\
\hline DEBT_GDP & -0.7876 & Debt \\
\hline DSERV_EXP & -0.8467 & Debt \\
\hline DSERV_RES & -0.8231 & Debt \\
\hline GR_GCAP & 0.7574 & Econ.Dom. \\
\hline GR_IMP & 0.7055 & Econ.Ext \\
\hline RER_DEV & -0.8145 & Econ.Ext \\
\hline METAL_EXP & -0.7030 & Commodities \\
\hline HERFOPP & -0.7522 & Institutional \\
\hline
\end{tabular}

Factor 2

\begin{tabular}{|l|r|l|}
\hline BANKROE & -0.6816 & Bank \\
\hline BCRED_BDEP & -0.7015 & Bank \\
\hline DCREDPUB_GDF & -0.7074 & Bank \\
\hline DCREDGDP & -0.6966 & Bank \\
\hline ARR_TDEBT & 0.6919 & Debt \\
\hline LTDPNG_TDEBT & 0.7465 & Debt \\
\hline GDSAV_GDP & -0.7005 & Econ.Dom. \\
\hline ERVOL & -0.7166 & Econ.Ext \\
\hline BURQUAL & -0.7420 & Institutional \\
\hline HERFGOV & 0.7019 & Institutional \\
\hline
\end{tabular}

Factor 3

\begin{tabular}{|l|r|l|}
\hline BANKCONC & -0.4857 & Bank \\
\hline PCRED_DMB & -0.5874 & Bank \\
\hline REDU_TDEBT & -0.6471 & Debt \\
\hline RES_DEBT & -0.4807 & Debt \\
\hline INFLAT & 0.5656 & Econ.Dom. \\
\hline GR_RES & -0.5860 & Econ.Ext. \\
\hline RER_DEV & 0.5160 & Econ.Ext. \\
\hline AGRI_EXP & 0.5646 & Commodities \\
\hline FOOD_IMP & 0.4667 & Commodities \\
\hline INTSPREAD & 0.7616 & Financial \\
\hline
\end{tabular}

Factor 4

\begin{tabular}{|l|r|l|}
\hline DMBANKAS & -0.6147 & Bank \\
\hline FSDEPOS & -0.4936 & Bank \\
\hline LIQLIAB & -0.5122 & Bank \\
\hline AGRI_IMP & -0.5176 & Commodities \\
\hline FUEL_IMP & -0.5355 & Commodities \\
\hline METAL_IMP & -0.4799 & Commodities \\
\hline PETROL & -0.4914 & Commodities \\
\hline GR_GDPUSA & -0.6409 & global \\
\hline GDPWORLD & -0.5367 & global \\
\hline SOCIOECO & 0.8461 & institutional \\
\hline
\end{tabular}

Factor 5

\begin{tabular}{|l|r|l|}
\hline BANKZ & 0.5058 & Bank \\
\hline CBASSET & -0.4014 & Bank \\
\hline DCREDPUB_GDP & -0.3908 & Bank \\
\hline RGDPCAP_GR & 0.5624 & Econ.Dom. \\
\hline GR_GOVREV & -0.4146 & Econ.Dom. \\
\hline GR_VA_AGRI & -0.8686 & Commodities \\
\hline FOOD_EXP & -0.5284 & Commodities \\
\hline DEMACC & -0.5537 & institutional \\
\hline INTCONFL & -0.5194 & institutional \\
\hline LAWORD & 0.5003 & institutional \\
\hline
\end{tabular}

Factor 6

\begin{tabular}{|l|r|l|}
\hline DCREDPUB_GDP & -0.3684 & Bank \\
\hline PCRED_DMB & -0.4172 & Bank \\
\hline IMF_GDP & 0.4253 & Debt \\
\hline ERVOL & 0.3756 & Econ.Ext. \\
\hline AGRI_IMP & 0.5827 & Commodities \\
\hline FUEL_EXP & -0.5469 & Commodities \\
\hline PETROL & 0.3916 & Commodities \\
\hline GR_GDPUSA & 0.3748 & Global \\
\hline INVPROF & -0.7557 & institutional \\
\hline SOCIOECO & -0.5621 & institutional \\
\hline
\end{tabular}

Factor 7

\begin{tabular}{|l|r|l|}
\hline BANKCONC & -0.3844 & Bank \\
\hline LTDPPG_TDEBT & 0.5213 & Debt \\
\hline GR_M2 & 0.3778 & Econ.Dom. \\
\hline GR_RES & -0.5761 & Econ.Ext. \\
\hline M2RES & 0.3762 & Econ.Ext. \\
\hline IMPCOV & -0.5767 & Econ.Ext. \\
\hline FOOD_IMP & -0.5306 & Commodities \\
\hline HERFGOV & 0.4058 & institutional \\
\hline HERFOPP & -0.4110 & institutional \\
\hline LAWORD & 0.5088 & institutional \\
\hline
\end{tabular}

Factor 8

\begin{tabular}{|l|r|l|}
\hline BANKCONC & -0.3333 & Bank \\
\hline CBASSET & -0.6482 & Bank \\
\hline DCREDPUB_GDP & -0.3647 & Bank \\
\hline NETINTMG & -0.4587 & Bank \\
\hline STD_DEBT & 0.3313 & Debt \\
\hline INDPROD & 0.3354 & Econ.Dom. \\
\hline GR_UNEMPL & 0.4188 & Econ.Dom. \\
\hline ERVOL & 0.4491 & Econ.Ext. \\
\hline AGRI_IMP & 0.3317 & Commodities \\
\hline BURQUAL & 0.5127 & institutional \\
\hline
\end{tabular}

Factor 9

\begin{tabular}{|l|r|l|}
\hline BANKZ & -0.6375 & Bank \\
\hline CBASSET & 0.2946 & Bank \\
\hline LTDPNG_TDEBT & 0.2888 & Debt \\
\hline RGDPGR & -0.2946 & Econ.Dom. \\
\hline GR_GCAP & -0.4027 & Econ.Dom. \\
\hline FA_GDP & -0.3342 & Econ.Ext. \\
\hline METAL_IMP & -0.3279 & Commodities \\
\hline GR_GDPUSA & 0.3037 & Global \\
\hline GOVSTAB & -0.4054 & institutional \\
\hline INVPROF & -0.2914 & institutional \\
\hline
\end{tabular}




\section{MEXICO}

For each of the 7 factors: ten variables with highest correlation

Factor 1

\begin{tabular}{|l|c|l|}
\hline BANKCONC & 0.7472 & bank \\
\hline D_FSDEPOS & 0.6907 & bank \\
\hline D_LIQLIAB & 0.6972 & bank \\
\hline D_LTPPG_DEBT & 0.6865 & debt \\
\hline RER_DEV & -0.8636 & ext eco \\
\hline CA_GDP & -0.7453 & ext eco \\
\hline D_AGRI_IMP & -0.7558 & comm \\
\hline D_FUEL_EXP & -0.6946 & comm \\
\hline D_METAL_EXP & -0.7417 & comm \\
\hline D_METAL_IMP & -0.7948 & comm \\
\hline
\end{tabular}

Factor 4

\begin{tabular}{|l|r|l|}
\hline INDPROD & 0.5558 & dom eco \\
\hline DSERV_RES & 0.5174 & debt \\
\hline GR_IMP & 0.4673 & ext eco \\
\hline IMPCOV & -0.4970 & ext eco \\
\hline D_GDPUSA & 0.4992 & global \\
\hline USYIELD & 0.4810 & global \\
\hline TBILL & 0.4749 & global \\
\hline D_CORRUPT & -0.5330 & instit \\
\hline D_GOVSTAB & 0.4555 & instit \\
\hline D_INVPROF & 0.4635 & instit \\
\hline
\end{tabular}

Factor 7

\begin{tabular}{|l|r|l|}
\hline ARR_TDEBT & 0.3411 & debt \\
\hline INDPROD & -0.3972 & dom eco \\
\hline GOVBAL_GDP & -0.3858 & dom eco \\
\hline D_CETES & 0.2992 & dom eco \\
\hline GR_IMP & -0.4727 & ext eco \\
\hline FA_GDP & -0.3411 & ext eco \\
\hline NETPI_GDP & -0.5651 & ext eco \\
\hline D_GDPWORLD & -0.2998 & global \\
\hline D_LAWORD & 0.3505 & instit \\
\hline D_SOCIOECO & 0.5133 & instit \\
\hline
\end{tabular}

Factor 2

\begin{tabular}{|l|r|l|}
\hline DCREDBANK & -0.7681 & bank \\
\hline DEBT_GDP & -0.8818 & debt \\
\hline IMF_GDP & -0.9061 & debt \\
\hline STD_DEBT & -0.5993 & debt \\
\hline INFLAT & -0.9472 & dom eco \\
\hline GFCAP_GDP & 0.6923 & dom eco \\
\hline D_TRD_OPEN & -0.5842 & ext eco \\
\hline D_AGRI_EXP & -0.7492 & comm \\
\hline D_FOOD_EXP & -0.7013 & comm \\
\hline D_SOCIOECO & 0.6267 & instit \\
\hline
\end{tabular}

Factor 3

\begin{tabular}{|l|r|l|}
\hline D_BCRED_BDEP & -0.5435 & bank \\
\hline D_DMBANKAS & -0.5725 & bank \\
\hline DCREDPUB & 0.7434 & bank \\
\hline D_RES_DEBT & 0.6375 & debt \\
\hline REALINT & -0.7373 & dom eco \\
\hline GDSAV_GDP & 0.6997 & dom eco \\
\hline D_CETES & -0.5522 & dom eco \\
\hline GR_RES & 0.5996 & ext eco \\
\hline D_BURQUAL & -0.7458 & instit \\
\hline D_INTCONFL & -0.6049 & instit \\
\hline
\end{tabular}

Factor 5

\begin{tabular}{|l|r|l|}
\hline BANKROE & -0.5144 & bank \\
\hline D_PCRED_DMB & -0.4602 & bank \\
\hline D_PCRED_OTH & -0.4381 & bank \\
\hline ARR_TDEBT & -0.4122 & debt \\
\hline REDU_TDEBT & 0.5016 & debt \\
\hline M2MULT & 0.5794 & dom eco \\
\hline INVCHG_GDP & -0.4446 & dom eco \\
\hline TOT & -0.5492 & ext eco \\
\hline NETFDI_GDP & 0.4498 & ext eco \\
\hline D_GDPWORLD & -0.4678 & global \\
\hline
\end{tabular}

Factor 6

\begin{tabular}{|l|r|l|}
\hline D_DMBANKAS & -0.6643 & bank \\
\hline D_FSDEPOS & -0.4292 & bank \\
\hline D_LIQLIAB & -0.4885 & bank \\
\hline D_PCRED_DMB & -0.5294 & bank \\
\hline D_PCRED_OTH & -0.5339 & bank \\
\hline D_LTPNG_DEBT & 0.7329 & debt \\
\hline D_LTPPG_DEBT & -0.3978 & debt \\
\hline D_FOOD_IMP & 0.5013 & comm \\
\hline D_GOVSTAB & -0.5828 & instit \\
\hline HERFOPP & 0.4384 & instit \\
\hline
\end{tabular}




\section{Ordered Logit estimation results}

\section{Argentina}

Static Factor Model

$\begin{array}{lrrl}\text { Variable } & \text { Coefficient } & \text { Std. Error } & \text { Prob. } \\ \text { SF1 } & -3.8583 & 0.9363 & 0.0000 \\ \text { SF2 } & 6.0855 & 1.3795 & 0.0000 \\ \text { SF3 } & -8.8692 & 2.0522 & 0.0000 \\ \text { SF4 } & 1.9512 & 0.5782 & 0.0007 \\ \text { SF5 } & -2.1185 & 0.7584 & 0.0052 \\ \text { SF6 } & 0.7558 & 0.7446 & 0.3101 \\ \text { SF7 } & -5.3066 & 1.3505 & 0.0001 \\ \text { SF8 } & -1.5626 & 0.5041 & 0.0019 \\ \text { SF9 } & 1.7025 & 0.7712 & 0.0273 \\ \text { SF10 } & -5.4003 & 1.3482 & 0.0001 \\ \text { SF11 } & 2.4378 & 1.0833 & 0.0244\end{array}$

\begin{tabular}{lrr}
\multicolumn{3}{c}{ Limit Points } \\
LIMIT_1:C(12) & 24.31531 & 5.205633 \\
LIMIT_2:C(13) & 27.75734 & 5.67798 \\
LIMIT_3:C(14) & 32.33869 & 6.319964 \\
& \\
Pseudo R-squared & 0.7454 \\
Schwarz criterion & 0.7540 \\
Hannan-Quinn criter. & 0.6165 \\
LR statistic & 224.3511 \\
Prob(LR statistic) & - \\
Akaike info criterion & 0.5231 \\
Log likelihood & - \\
Restr. log likelihood & -150.3070 \\
Avg. log likelihood & - & 0.1915 \\
Adjusted Pseudo R2 & & 0.6723
\end{tabular}

Dynamic Factor Model (q 4, p 2)

$\begin{array}{lrrl}\text { Variable } & \text { Coefficient } & \text { Std. Error } & \text { Prob. } \\ \text { DF1 } & -16.9394 & 4.4928 & 0.0002 \\ \text { DF2 } & 15.7001 & 3.5181 & 0.0000 \\ \text { DF3 } & -33.7729 & 8.0580 & 0.0000 \\ \text { DF4 } & 1.9719 & 1.3834 & 0.1540 \\ \text { DF5 } & -15.3724 & 6.6354 & 0.0205 \\ \text { DF6 } & 5.2748 & 3.0599 & 0.0847 \\ \text { DF7 } & -14.7328 & 3.3648 & 0.0000 \\ \text { DF8 } & 0.3376 & 2.2714 & 0.8818 \\ \text { DF9 } & 5.5524 & 2.4638 & 0.0242 \\ \text { DF10 } & -17.1661 & 4.1700 & 0.0000 \\ \text { DF11 } & -16.0372 & 6.3991 & 0.0122\end{array}$

Limit Points

$\begin{array}{llll}\text { LIMIT_1:C(12) } & 78.66688 & 23.41531 & 0.0008 \\ \text { LIMIT_2:C(13) } & 82.99804 & 23.82539 & 0.0005 \\ \text { LIMIT_3:C(14) } & 87.19589 & 24.18201 & 0.0003\end{array}$

Pseudo R-squared $\quad 0.7783$

Schwarz criterion $\quad 0.7045$

Hannan-Quinn criter. $\quad 0.5671$

LR statistic 234.2336

Prob(LR statistic)

Akaike info criterion $\quad 0.4737$

Log likelihood $\quad 33.3657$

Restr. log likelihood $\quad-\quad 150.4825$

Avg. log likelihood $\quad$ - $\quad 0.1668$

Adjusted Pseudo R2 $\quad 0.7052$ 


\section{Argentina - excluding institutional indicators}

Static Factor Model

\section{Variable}

SF1

SF2

SF3

SF4

SF5

SF6

SF7

SF8

SF9

SF10

Limit Points

LIMIT_1:C(11)

LIMIT_2:C(12)

LIMIT_3:C(13)

Pseudo R-squared

Schwarz criterion

Hannan-Quinn criter.

LR statistic

Prob(LR statistic)

Akaike info criterion

Log likelihood

Restr. log likelihood

Avg. log likelihood

Adjusted Pseudo R2

$\begin{array}{rrl}\text { Coefficient } & \text { Std. Error } & \text { Prob. } \\ -0.8022 & 0.3721 & 0.0311 \\ -1.1398 & 0.4154 & 0.0061 \\ -1.6924 & 0.7783 & 0.0297 \\ -0.7198 & 0.2442 & 0.0032 \\ 0.6460 & 0.4854 & 0.1832 \\ -0.1896 & 0.3604 & 0.5987 \\ 1.1974 & 0.4509 & 0.0079 \\ 0.8275 & 0.5232 & 0.1137 \\ 0.6956 & 0.2802 & 0.0130 \\ 1.5930 & 0.5126 & 0.0019\end{array}$

Dynamic
Variable
DF1

DF2

DF3

DF4

DF5

DF6

DF7

DF8

DF9

DF10

\section{Limit Points}

LIMIT_1:C(11)

LIMIT_2:C(12)

LIMIT_3:C(13)

$\begin{array}{rr}5.227112 & 0.856032 \\ 7.910543 & 1.173544 \\ & 0.5398 \\ & 1.0368 \\ 0.9092 \\ 162.4752 \\ 0.0000 \\ 0.8224 \\ -69.2449 \\ -150.4825 \\ -0.3462 \\ 0.4734\end{array}$

Pseudo R-squared

Schwarz criterion

Hannan-Quinn criter.

R statistic

Prob(LR statistic)

Akaike info criterion

Log likelihood

0.5543

0.2384

0.2635

$0.0583 \quad 0.3854$

Restr. log likelihood

Avg. log likelihood

Adjusted Pseudo R2

0.4734
Prob.

0.1044

0.0027

0.0239

0.0013

0.0000

0.0097

0.0004

0.3222

0.3657

0.8798

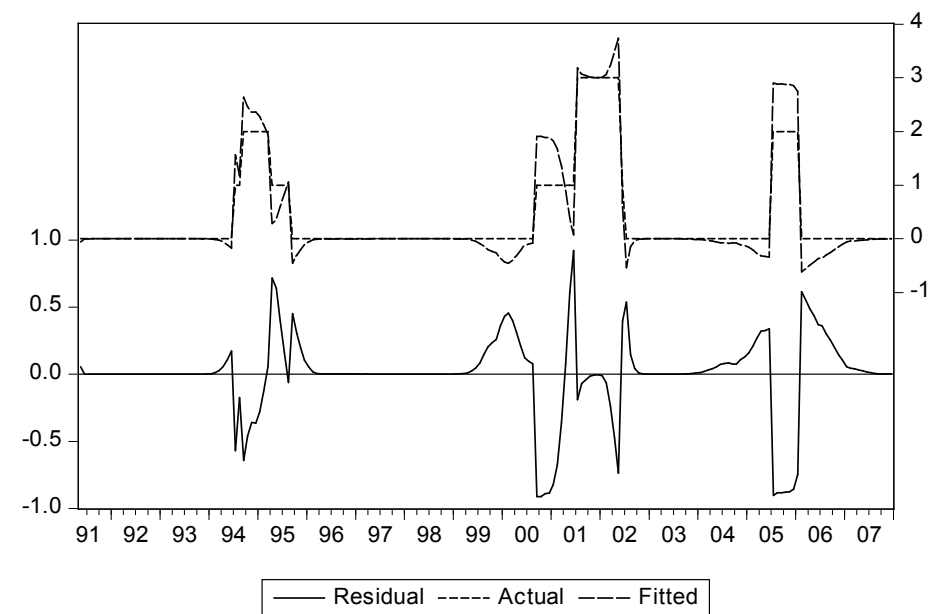




\section{Brazil}

Static Factor Model

\section{Variable}

SFM1

SFM2

SFM3

SFM4

SFM5

SFM6

SFM7

SFM8

SFM9

CONTAG

ELECEXEYEAR
Coefficient

$-0.151451$

0.201862

0.255185

$-0.185297$

$-0.220431$

$-0.481383$

0.221075

$-0.093765$

0.445396

$-0.038387$

0.50863

\section{Limit Points}

LIMIT_1:C(12)

1.491236

LIMIT_2:C(13)

2.420088

5.223494

Pseudo R-squared

Schwarz criterion

Hannan-Quinn criter.

LR statistic

Prob(LR statistic)

Akaike info criterion

Log likelihood

Restr. log likelihood

Avg. log likelihood

Adjusted Pseudo R2
Dynamic Factor Model (q 3, p 2)

$\begin{array}{rl}\text { Std. Error } & \text { Prob. } \\ 0.06051 & 0.0123 \\ 0.074308 & 0.0066 \\ 0.091236 & 0.0052 \\ 0.093921 & 0.0485 \\ 0.150569 & 0.1432 \\ 0.165013 & 0.0035 \\ 0.137723 & 0.1084 \\ 0.132033 & 0.4776 \\ 0.147062 & 0.0025 \\ 0.723748 & 0.9577 \\ 0.557482 & 0.3616\end{array}$

Variable

DF1

DF2

DF3

DF4

DF5

DF6

DF7

DF8

DF9

CONTAG

ELECEXEYEAR
Coefficient

$-0.093127$

0.423517

1.287673

$-0.621748$

0.728228

$-2.152564$

0.463516

0.825458

1.801576

$-0.61224$

1.062805
Std. Error

0.079353

0.132326

0.33803

0.174039

0.359769

0.555648

0.27275

0.319504

0.43153

0.797549

0.688428

\section{Limit Points}

0.362886

0.387949

0.696023

0.222879

1.859625

1.700474

65.4653

0

1.591676

$-114.13$

$-146.8626$

$-0.708882$

0.14798
2.930082

0.752875

0.781824

1.075833

LIMIT_2:C(13)

3.981299

7.033818

Pseudo R-squared

0.299977

Schwarz criterion

1.71897

Hannan-Quinn criter.

LR statistic

1.559819

88.11075

Prob(LR statistic)

Akaike info criterion

Log likelihood

Restr. log likelihood

Avg. log likelihood

Adjusted Pseudo R2

1.451021

$-102.8072$

$-146.8626$

$-0.638554$

0.22508
Prob.

0.2406

0.0014

0.0001

0.0004

0.043

0.0001

0.0892

0.0098

0.4427

0.1226

0.0001

0 


\section{Mexico}

Static Factor Model

\section{Variable}

SF1

SF2

$\mathrm{SF} 3$

SF4

SF5

SF6

SF7

CONTAG

ELECEXEYEAR
Coefficient

$-1.3022$

$-2.4353$

$-1.0909$

1.6104

1.2663

$-0.8414$

0.7497

2.3571

1.9721

Limit Points

LIMIT_1:C(10)

LIMIT_2:C(11)

LIMIT_3:C(12)

12.18136

14.4149

17.29079

Pseudo R-squared

Schwarz criterion

Hannan-Quinn criter.

LR statistic

Prob(LR statistic)

Akaike info criterion

Log likelihood

Restr. log likelihood

Avg. log likelihood

Adjusted Pseudo R2

$\begin{array}{rl}\text { Std. Error } & \text { Prob. } \\ 0.5939 & 0.0283 \\ 0.9528 & 0.0106 \\ 0.2609 & 0.0000 \\ 0.5572 & 0.0039 \\ 0.6412 & 0.0483 \\ 0.4901 & 0.0860 \\ 0.2596 & 0.0039 \\ 1.4523 & 0.1046 \\ 1.1801 & 0.0947\end{array}$

4.419629

4.508815

4.621632

0.63111

0.75448

0.64272

168.45610

0.56696

- 49.23168

- 133.45970

- 0.22792

0.56368

0.0058

0.0014

0.0002

Dynamic Factor Model (q 3, p 2)

Variable

DF1

DF2

DF3

DF4

DF5

DF6

DF7

CONTAG

ELECEXEYEAR

Coefficient

0.9429

$-1.5622$

$-0.9340$

1.1777

0.5129

0.2829

0.8179

1.6256

2.4562
Std. Error

0.5497

0.7622

0.1889

0.3946

0.4882

0.5419

0.2106

1.0997

1.0989

\section{Limit Points}

8.691282
10.94631
15.07563

3.858121

3.926914

4.214669

0.62531

0.76164

0.64988

166.90820

LR statistic

Prob(LR statistic)

Akaike info criterion

0.57413

Log likelihood

50.00563

Restr. log likelihood

Avg. log likelihood

Adjusted Pseudo R2
Prob.

0.0863

0.0404

0.0000

0.0028

0.2934

0.6016

0.0001

0.1393

0.0254

0.0243

0.0053

0.0003 


\section{Acknowledgements}

We thank Ningchuan Yang for excellent research assistance, Domenico Giannone for making the Matlab code of Doz, Giannone and Reichlin (2011) available, and seminar participants at The economics and econometrics of recurring financial market crises, Waterloo, Ontario, CIRANO Montréal, and the University of Groningen. 


\section{References}

Abiad, A. (2003), "Early warning systems: A survey and a regime-switching approach", IMF Working Paper 32, International Monetary Fund, Washington, DC.

Alvarez Plata, P. and M. Schrooten (2004), "Misleading indicators? The Argentinean currency crisis", Journal of Policy Modeling, 26, 587-603.

Amengual, D. and M. Watson (2007), "Consistent estimation of the number of factors in a large $N$ and $T$ panel", Journal of Business $\&$ Economic Statistics, 25, 91-96.

Aruoba, S. Borağan, Francis X. Diebold, and Chiara Scotti (2009), "Real-time measurement of business conditions", Journal of Economic $\mathscr{G}$ Business Statistics, 27, 417-427.

Bai, J. and S. Ng (2002), "Determining the number of factors in approximate factor models", Econometrica, 70, 191-221.

Bai, J. and S. Ng (2007), "Determining the number of primitive shocks in factor models", Journal of Business and Economic Statistics, 25, 52-60.

Barhoumi, Karim, Olivier Darné, and Laurent Ferrara (2010), "Are disaggregate data useful for forecasting French GDP with dynamic factor models?", Journal of Forecasting, 29, 132144 .

Beckmann, D., L. Menkhoff and K. Sawischlewski (2006), "Robust lessons about practical early warning systems", Journal of Policy Modeling, 28, 163-193.

Berg, J. van den, B. Candelon and J.P. Urbain (2008), "A cautious note on the use of panel models to predict financial crises", Economics Letters, 101, 80-83.

Beziz, P. and G. Petit (1997), "The Mexican crisis: Were signals inadequate?", Cambridge Review of International Affairs, 11, 141-159.

Breitung, Jörg and Sandra Eickmeier (2006), "Dynamic factor models", Algemeines Statistisches Archiv, 90, 27-42. 
Breuer, J.B. (2004), "An exegesis on currency and banking crises", Journal of Economic Surveys, 18, 293-320.

Bussière, M. and C. Mulder (2000), "Political instability and economic vulnerability", International Journal of Finance and Economics, 5, 309-330.

Cerro, A.M. and V.D. Iajya (2009), "Currency crises and institutions: The case of Argentina 1862-2004", Anales de la XLIII Reunin Anual de la Asociacin Argentina de Economa Poltica, Mendoza.

Chang, R. and A. Velasco (1998), "Financial crises in emerging markets: A canonical model", NBER Working Paper 6606, National Bureau of Economic Research, Cambridge, MA.

Cipollini, Andrea and George Kapetanios (2009), "Forecasting financial crises and contagion in Asia using dynamic factor analysis", Journal of Empirical Finance, 16, 188-200.

Doz, Catherine, Domenico Giannone, and Lucrezia Reichlin (2011), "A two-step estimator for large approximate dynamic factor models based on Kalman filtering", Journal of Econometrics. Annals Issue on Forecasting, 164, 188-205.

Eichengreen, B., A.K. Rose, and C. Wyplosz (1995), "Exchange rate mayhem: The antecedents and aftermath of speculative attacks", Economic Policy, 21, 251-312.

Forni, Mario, Domenico Giannone, Marco Lippi, and Lucrezia Reichlin (2009), "Opening the black box: Structural factor models with large cross sections", Econometric Theory, 25, 1319-1347.

Forni, Mario, Marc Hallin, Marco Lippi, and Lucrezia Reichlin (2005), "The generalized dynamic factor model: One-sided estimation and forecasting", Journal of the American Statistical Association, 100, 830-840.

Hallin, M. and R. Liška (2007), "Determining the number of factors in the general dynamic 
factor model", Journal of the American Statistical Association, 102, 603-617.

Harding, Matthew C. (2009), "Structural estimation of high-dimensional factor models", mimeo, Stanford University.

Herrera, S. and C. Garcia (1999), "A user's guide to an early warning system of macroeconomic vulnerability for LAC countries", Policy Research Working Paper 2233, World Bank, Washington, DC.

Jacobs, J.P.A.M., G.H. Kuper, and Lestano (2008), "Currency crises in Asia: A multivariate logit approach", in S.-J. Kim and M. McKenzie, editors, Asia Pacific Financial Markets: Integration, Innovation and Challenges, volume 8 of International Finance Review, Elsevier, Amsterdam, 157-173.

Jacobs, J.P.A.M. and P.W. Otter (2008), "Determining the number of factors and lag order in dynamic factor models: A minimum entropy approach", Econometric Reviews, 27, 385-397.

Kamin, S.B. and O.D. Babson (1999), "The contribution of domestic and external factors to Latin American devaluation crises: An early warning systems approach", International Finance Discussion Papers 645, Board of Governors of the Federal Reserve System, Washington, DC.

Kaminsky, G.L, A. Mati and N. Choueiri (2009), "Thirty years of currency crises in Argentina: External shocks or domestic fragility?", NBER Working Papers 15478, National Bureau of Economic Research, Cambridge, MA.

Kaminsky, G.L., S. Lizondo, and C.M. Reinhart (1998), "Leading indicators of currency crisis", IMF Staff Papers 45/1, International Monetary Fund, Washington, DC.

Kaminsky, Graziela L. (2006), "Currency crises: Are they all the same?", Journal of International Money and Finance, 25, 503-527. 
Kaminsky, Graziela L. and Carmen M. Reinhart (1999), "The twin crises: The causes of banking and balance-of-payments problems", American Economic Review, 89, 473-500.

Kapetanios, G. (2010), "A testing procedure for determining the number of factors in approximate factor models with large datasets", Journal of Business 83 Economic Statistics, 28, 397-409.

Kapetanios, George and Massimiliano Marcellino (2009), "A parametric estimation method for dynamic factor models of large dimensions", Journal of Time Series Analysis, 30, $208-238$.

Kennedy, P. (2008), A Guide to Econometrics, Blackwell Publishing, Malden, MA.

Krugman, P. (1979), "A model of balance-of-payment crises", Journal of Money, Credit and Banking, 11, 311-325.

Krugman, P. (2003), "Crisis: The next generation?", in E. Helpman and E. Sadka, editors, Economic Policy in the International Economy: Essays in Honor of Assaf Razin, Cambridge University Press, Cambridge, MA, 15-32.

Manasse, P., N. Roubini and A. Schimmelpfennig (2003), "Predicting sovereign debt crises", IMF Working Papers 221, IMF, Washington.

McKinnon, R. and H. Pill (1997), "Credible economic liberalizations and overborrowing", American Economic Review, 87, 189-193.

Obstfeld, M. (1996), "Models of currency crises with self-fulfilling features", European Economic Review, 3-5, 1037-1047.

Onatski, A. (2009), "Testing hypotheses about the number of factors in large factor models", Econometrica, 77, 1447-1479.

Otter, Pieter W., Jan P.A.M. Jacobs, and Ard H.J. den Reijer (2011), “A criterion for the number of factors in a data-rich environment", Presented at the EEA-ESEM conference, 
Oslo, Norway, August.

Reinhart, C.M. and K.S. Rogoff (2009), This Time is Different: Eight Centuries of Financial Folly, Princeton University Press, Princeton and Oxford.

Rong Qian, Carmen M. Reinhart, Kenneth S. Rogoff (2010), "On graduation from default, inflation and banking crises: elusive or illusion?", NBER Working Paper 16168, National Bureau of Economic Research, Cambridge, MA.

Sachs, J.D., A. Tornell, and A. Velasco (1996), "Financial crises in emerging markets: The lessons from 1995 (with comments and discussion)", Brookings Papers on Economic Activity, 1, 147-198.

Schumacher, Christian (2007), "Forecasting German GDP using alternative factor models based on large datasets", Journal of Forecasting, 26, 271302.

Stock, James H. and Mark W. Watson (1998), "Diffusion indexes", Working paper 6702, National Bureau of Economic Research.

Stock, James H. and Mark W. Watson (2002), "Macroeconomic forecasting using diffusion indexes", Journal of Business and Economic Statistics, 20, 147-162.

Stock, James H. and Mark W. Watson (2005), "Implications of dynamic factor models for VAR analysis", Working paper 11467, National Bureau of Economic Research.

Stock, James H. and Mark W. Watson (2011), "Dynamic factor models", in Michael P. Clements and David F. Hendry, editors, Oxford Handbook of Economic Forecasting, Oxford University Press, Oxford, UK, chapter 2. 